\title{
EFISIENSI SISTEM MULTI SOIL LAYERING PADA PENGOLAHAN AIR LIMBAH DOMESTIK PADA DAERAH PERKOTAAN PADAT PENDUDUK
}

\author{
Riyanto Haribowo, Sonia Megah, Windy Rosita \\ Jurusan Teknik Pengairan, Fakultas Teknik, Universitas Brawijaya, Indonesia 65145 \\ riyanto_haribowo@ub.ac.id
}

\begin{abstract}
ABSTRAK: Pembuangan air limbah domestik di daerah perkotaan tanpa melalui pengolahan yang efektif dapat mengakibatkan kontaminasi air permukaan di sekitarnya. Penelitian ini bertujuan untuk mengamati kinerja IPAL dengan metode multi-soil-layering (MSL) dalam mengolah limbah domestik. Parameter limbah domestik yang digunakan adalah Total Suspended Solids (TSS), Total Dissolved Solids (TDS), pH, Dissolved Oxygen (DO), Kekeruhan, dan Daya Hantar Listrik (DHL). Percobaan terdiri dari 2 tahap, pada tahap 1, reaktor yang terdiri dari 3 sekat masing-masing diisi dengan lapisan batuan yang terdiri dari kerikil, zeolit, serta campuran kerikil dan zeolit. Pada tahap 2, dari hasil yang terbaik pada tahap 1, masing-masing sekat ditambahkan dengan isian campuran tanah andosol dan arang tempurung kelapa, campuran tanah andosol dan arang jerami padi, serta campuran tanah andosol dan serbuk gergaji. Dari hasil penelitian didapatkan reaktor yang paling efektif untuk mengolah limbah domestik adalah MSL dengan lapisan penyusun zeolite dan dengan isian campuran tanah andosol dan arang tempurung kelapa, dengan efisiensi untuk TSS, TDS, pH, DO, Kekeruhan dan DHL masing-masing adalah sebesar $64,55 \% ; 24,52 \% ; 4,89 \%$; 81,88\%; $76,69 \%$ dan $31,77 \%$.
\end{abstract}

Kata Kunci: limbah domestik, metode MSL, efisiensi

\begin{abstract}
The discharge of domestic wastewater in urban areas without effective treatment may result in contamination of surrounding surface water. This study explored the wastewater treatment performance of multi-soil-layering (MSL) on domestic wastewater. Domestic wastewater parameter was use are Total Suspended Solids (TSS), Total Dissolved Solids $(T D S), p H$, Dissolved Oxygen (DO), Turbidity and Electrical conductivity (DHL). The experiment consisted of two stages, in stage 1, three partition in the reaktor was filled with layers of rock consisting of gravel, zeolite, and mix between gravel and zeolite. In stage 2, from the best results in stage 1 , then added with stuffing mixture of andosol soil and coconut shell charcoal, mixture of andosol soil and sawdust and also mixture of andosol soil and rice straw charcoal. From the result it can be concluded that MSL with zeolite layer and mixture of andosol soil and coconut shell charcoal are the best result to purify the domestic wastewater. The efficiency for TSS, TDS, pH, DO, Turbidity and EC was $64.55 \% ; 24.52 \%$; $4.89 \% ; 81.88 \%$; $76.69 \%$ and $31,77 \%$ respectively.
\end{abstract}

Keywords: domestic waste, MSL method, efficiency

Limbah cair terbesar berasal dari hasil aktivitas rumah tangga. Hal ini dikarenakan jumlah penduduk yang sangat besar. Peningkatan jumlah penduduk diikuti peningkatan produksi air limbah khususnya air limbah domestik. Berdasarkan Peraturan Daerah Kota Malang No. 3 Tahun 2017 air limbah domestik adalah air limbah yang berasal dari usaha dan/atau kegiatan pemukiman, rumah makan, perkantoran dan asrama.

Air limbah domestik di Kota Malang belum seluruhnya dapat tertangani, selain itu sebagian besar orang membuang limbah domestik langsung ke selokan yang ada di depan rumah maupun di belakang rumah, tanpa diolah terlebih dahulu. Akibatnya sungai yang menjadi tempat bemuaranya selokan 
berpotensi tercemar. Selain bisa menyebabkan ikan-ikan mati, zat-zat polutan yang terkandung didalam limbah juga bisa menjadi sumber penyakit seperti kolera, disentri, dan berbagai penyakit lain (Rini et al, 2011). Oleh karena itu, perlu dilakukan pengelolaan air limbah domestik sebelum dibuang langsung ke sungai.

Limbah domestik juga menyebabkan adanya toksisitas pada perairan yang berdampak pada ekosistem. Dalam sebuah penelitian menunjukkan bahwa toksisitas merupakan masalah yang tidak bisa diabaikan karena menunjukkan bahwa air dari daerah pemukiman, kadang-kadang cukup beracun untuk mempengaruhi habitat air, dan tingkat toksisitas ini harus dikelola (Haribowo et al., 2017). Prosedur analisis polusi untuk desain pembuangan limbah dapat diterapkan untuk manajemen toksisitas (Yamashita et al., 2012).

Berbagai teknik pengolahan limbah cair telah dikembangkan. Namun, masing-masing teknik pengolahan limbah cair ini penggunaannya terbatas dan kurang menguntungkan. Sebagai contoh, karbon aktif hanya melibatkan adsorpsi polutan tanpa dekomposisi. Oksidasi kimia tidak dapat memineralisasi semua senyawa organik dan hanya cocok untuk menghilangkan polutan dengan konsentrasi tinggi. Pengolahan secara biologis memiliki kelemahan yaitu kecepatan reaksi lambat, pembuangan lumpur aktif yang sulit, $\mathrm{pH}$ dan teperatur harus dikontrol. Suatu teknik pengolahan limbah organik yang lebih efektif, efisien, mudah, dan murah perlu dikembangkan yaitu metode Multi Soil Layering (MSL) (Irmanto \& Suyata, 2009).

Sistem MSL merupakan metoda pengolahan limbah cair yang memanfaatkan kemampuan tanah sebagai media utama dalam menyisihkan parameter pencemar dan meningkatkan kemampuan tanah tersebut dengan memperbaiki strukturnya (Lahdib, 2016). Sistem MSL dibentuk pada sebuah konstruksi atau reaktor yang tersusun atas lapisan capuran tanah dan lapisan batuan yang dibentuk seperti susunan batu bata. Lapisan campuran tanah terdiri dari tanah terpilih, arang sebagai unsur karbon, material organik dan material tambahan lain seperti bijih besi (Yi et al, 2015). Lapisan batuan yang bisa digunakan seperti kerikil, zeolit, perlit, kombinasi zeolit perlit dan lain-lain tergantung jenis batuan yang ada (Attanandana et al, 2007; Wakatsuki et al, 1993).
Tanah merupakan sistem biologis, fisika dan kimia raksasa yang telah digunakan untuk pendaur dan pengolah limbah sejak dahulu. Peranan tanah tidak hanya sebagai media pertumbuhan tanaman saja, tetapi juga untuk tempat pembuangan limbah dari hewan, manusia dan industri. Saat ini peranan tanah untuk pengolahan limbah cair mendapat perhatian yang tinggi (Tahir et al, 1997).

Dari beberapa penelitian yang ada sebelumnya, metode MSL dapat menurunkan BOD dan COD sungai Uya di kepulauan Oki, Jepang sampai 90\% (Wakatsuki et al, 2001). Metode MSL juga dapat menurunkan BOD sebesar 98,8\% dan COD sebesar 93,6\% untuk pengolahan limbah doestik dari cafetaria dan toilet Universitas Kasetsart, Thailand (Luanmanee et al, 2000). Sistem MSL efektif digunakan untuk mengolah limbah selama 12,8 tahun. Namun, mungkin saja lebih pendek atau lebih panjang tergantung pada mutu limbah, kandungan dan jenis dari material organik, temperatur dan manajemen dari sistem tersebut (Wakatsuki et al, 1993). Pada penelitian ini yang membedakan dengan penelitian sebelumnya terletak pada variasi komposisi material organik dan pengujian material untuk menentukan komposisi material terbaik dalam mengolah limbah. Dimana material organiknya terdiri dari zeolit, kerikil, zeolite dan kerikil, campuran tanah dan arang aktif, campuran tanah dan serbuk gergaji dan campuran tanah dan jerami padi.

Penelitian ini bertujuan untuk mengetahui nilai efisiensi penyisihan parameter dan mengetahui perbandingan hasil pengolahan dengan metode MSL dan hasil pengolahan IPAL yang ada di Kelurahan Tlogomas.

\section{METODE PENELITIAN \\ Lokasi Penelitian}

Lokasi penelitian berada di Kelurahan Tlogomas, Kecamatan Lowokwaru, Kota Malang. Kelurahan Tlogomas merupakan salah satu dari 12 kelurahan yang ada di Kecamatan Lowokwaru, Kota Malang (Satria, 2013). Tempat penelitian dilakukan di IPAL yang berada di RT.04 RW.07 Kelurahan Tlogomas. 


\section{Analisis Limbah Cair Domestik Pada Bak Sedimentasi}

Limbah cair domestik yang digunakan untuk penelitian berasal dari limbah domestik MCK Terpadu Kelurahan Tlogomas yang terletak di RT.04 RW.07.

Analisa yang diamati adalah TSS, TDS, $\mathrm{pH}$, DO, Kekeruhan, dan Daya Hantar Listrik (DHL) (Tabel 1).

Tabel 1. Hasil Analisa Limbah Cair Domestik Pada Bak Sedimentasi 1

\begin{tabular}{|l|l|r|r|r|r|}
\hline No. & Parameter & $\begin{array}{c}\text { Sampel } \\
1\end{array}$ & \multicolumn{1}{c|}{$\begin{array}{c}\text { Sampel } \\
2\end{array}$} & $\begin{array}{c}\text { Sampel } \\
3\end{array}$ & \multicolumn{1}{c|}{$\begin{array}{c}\text { Baku } \\
\text { mutu }\end{array}$} \\
\hline 1. & $\mathrm{pH}$ & 7,30 & 6,60 & 6,70 & $6,0-9,0$ \\
\hline 2. & $\begin{array}{l}\text { TSS } \\
(\mathrm{mg} / \mathrm{L})\end{array}$ & 124,50 & 138,33 & 126,67 & 30 \\
\hline 3. & $\begin{array}{l}\text { TDS } \\
(\mathrm{mg} / \mathrm{L})\end{array}$ & 443,60 & 541,33 & 602,00 & 1.500 \\
\hline 4. & DO (mg/L) & 0,13 & 1,07 & 1,40 & 4,00 \\
\hline 5. & Kekeruhan & 256,00 & 447,00 & 765,00 & - \\
\hline 6. & DHL & 0,89 & 0,77 & 0,87 & - \\
\hline
\end{tabular}

Hasil analisa yang dibandingkan dengan Peraturan Pemerintah Republik Indonesia No. 82 Tahun 2001 tentang pengelolaan kualitas air dan pengendalian pencemaran air menunjukkan bahwa parameter yang akan diteliti ada yang melebihi baku mutu, oleh karena itu perlu adanya pengolahan limbah sebelum dilakukan pembuangan ke sungai.

\section{Tahapan Penelitian}

\section{Perhitungan Debit Air}

Perhitungan debit air digunakan untuk mengetahui berapa banyak limbah yang dihasilkan setiap rumah yang akan masuk dan diolah menggunakan reaktor Multi Soil Layering (MSL). Perhitungan debit sebagai berikut (Zevri, 2010):

$$
Q_{r}=\frac{f x\left[\left(80 \% x Q \times \sum \text { penduduk }\right)+(20 \% \times 30)\right]}{86.400 \text { detik/hari }}
$$

dengan:

Qr : Debit rata-rata air buangan (L/detik)

Fab : Faktor timbulan air buangan 0,5-0,8

Qam : Kebutuhan air bersih L/orang/hari.

\section{Perhitungan Dimensi Reaktor}

Perhitungan dimensi reaktor ini bertujuan untuk mengetahui seberapa besar ukuran reaktor yang nantinya akan digunakan dalam penelitian dengan metode MSL. Perhitungan dimensi reaktor sebagai berikut (BSN, 2008):

$$
\text { As }=\frac{\mathrm{Q}}{\mathrm{Vo}}
$$

dengan:

As : Luasan Permukaan

Q : Debit rata-rata air buangan (L/detik)

Vo : Kecepatan penyaringan (m/jam)

Dengan AS yang didapat maka dapat dihitung nilai dimensinya dengan rumus,

$$
\text { As }=\mathrm{p} \times 1
$$

dengan:

$$
\begin{array}{ll}
\text { As } & \text { : Luasan Permukaan } \\
\mathrm{p} & \text { : Panjang } \\
1 & \text { : Lebar (BSN, 2008) }
\end{array}
$$

\section{Penginstalan Reaktor}

Untuk penelitian ini, dilakukan penginstalan reaktor sebanyak 2 (dua) unit, yang dibedakan berdasarkan material organik pada lapisan batuan dan lapisan campuran tanah. Pada dua unit reaktor memiliki dimensi yang sama yang membedakan hanya komposisi material didalam reaktor. Pada reaktor tahap pertama diisi lapisan batuan yang terdiri dari kerikil, zeolit, serta kerikil dan zeolit. Pada reaktor tahap kedua ditambahkan lapisan campuran tanah yang terdiri dari campuran tanah andosol dan arang tempurung kelapa, campuran tanah andosol dan arang jerami padi, serta campuran tanah andosol dan serbuk gergaji.

Gambar 1 merupakan gambar reaktor tahap pertama. Pada tahap pertama dilakukan pengolahan limbah dengan reaktor yang berisi $40 \mathrm{~cm}$ zeolit, $40 \mathrm{~cm}$ kerikil, $30 \mathrm{~cm}$ zeolit dan $10 \mathrm{~cm}$ kerikil yang bertujuan untuk mencari penyekat manakah yang paling efisien, dan akan digunakan untuk mengolah limbah dalam kesatuan model MSL.

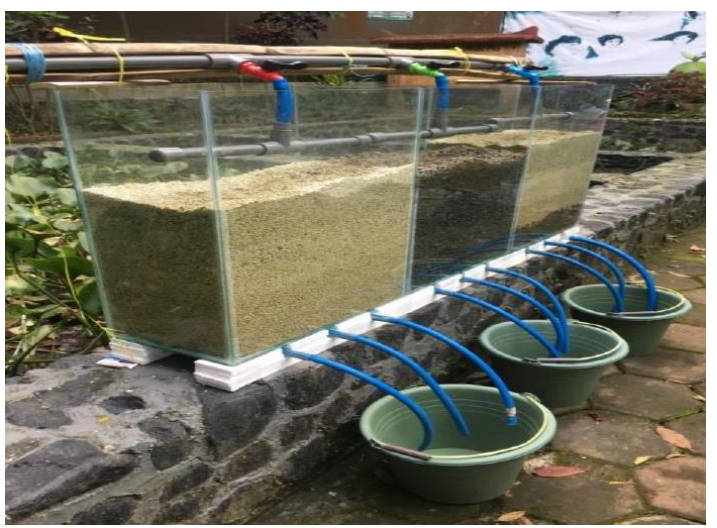

Gambar 1. Sketsa reaktor MSL model 1

Gambar 2 merupakan gambar reaktor tahap kedua, dimana hasil komposisi penyekat yang paling efisien dari tahap pertama akan ditambah dengan isian campuran tanah andosol 
dan arang tempurung kelapa, campuran tanah andosol dan serbuk gergaji, dan tanah andosol dan arang jerami padi. Dari reaktor ini akan didapatkan hasil efisiensi dari pengolahan limbah menggunakan metode MSL.

\section{Analisa Data}

\section{Pengambilan Sampel}

Pengambilan sampel dilakukan di bak IPAL Kelurahan Tlogomas pada bak sedimentasi pertama (bak nomor 3) dan outlet reaktor MSL. Pengambilan sampel untuk percobaan pendahuluan dilakukan pada tanggal $23 \mathrm{Mei}$ 2018 dan pengambilan sampel untuk percobaan utama dilakukan pada tanggal 24-26 Mei 2017. Pengambilan sampel dilakukan setiap 15 menit selama 2,5 jam. Pengujian sampel tersebut diuji menggunakan alat water quality checker Horiba series U-50.

\section{Efisiensi Metode MSL}

Efisiensi yang dimaksud adalah membandingkan kandungan limbah awal dan limbah sesudah dilakukan pengolahan menggunakan metode MSL. Efisiensi pengurangan parameter air limbah dapat dihitung dengan cara (Mutia, 2015):

$$
\operatorname{Kadar}(\%)=\frac{n_{\text {awal }}-n_{\text {akhir }}}{n_{\text {awal }}} \times 100 \%
$$

\section{Uji Statistik}

Uji yang digunakan adalah uji anova, dimana data yang digunakan adalah data hasil pengujian tahap pertama dan tahap kedua pengolahan limbah dengan metode MSL. Uji anova akan membandingkan nilai $F_{\text {hitung }}$ dan $\mathrm{F}_{\text {tabel }}$ (Sawyer, 2009).

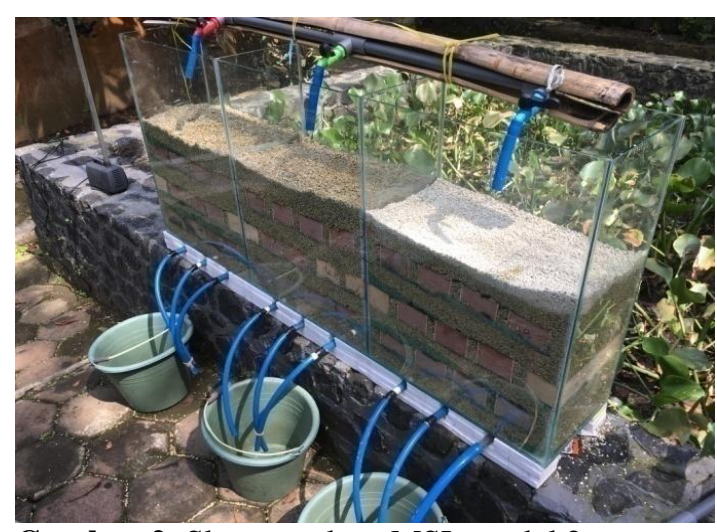

Gambar 2. Sketsa reaktor MSL model 2

\section{HASIL DAN PEMBAHASAN \\ 1. Perhitungan Debit}

$Q_{r}=\frac{0,8 \times[(80 \% \times 170 \times 5)+(20 \% \times 30)]}{86400}$

Qr $=0,0063 \mathrm{~L} /$ detik

Dari perhitungan diatas maka didapatkan debit satu unit rumah yang masuk ke dalam MCK terpadu Tlogomas sebesar 0,0063 L/detik.

\section{Perhitungan Dimensi Reaktor}

$$
\begin{aligned}
& \text { As }=\frac{0,0063 \mathrm{~L} / \text { detik }}{6 \mathrm{~m} / \mathrm{jam}} \\
& \text { As }=\frac{0,02 \mathrm{~m}^{3} / \mathrm{jam}}{6 \mathrm{~m} / \mathrm{jam}}=33,33 \mathrm{~cm}^{2}
\end{aligned}
$$

Dengan AS 33,33 $\mathrm{m}^{2}$ maka didapat

$33,33=8,2 \times 4,1$

$33,33=33,62$ (memenuhi)

Dari hasil diatas, nilai dimensi diperbesar lima kali, dan untuk tinggi reaktor dihitung berdasarkan penjumlahan lapisan penyangga dan lapisan pasir, sehingga didapat nilai dimensi sebesar $41 \times 20,5 \times 50 \mathrm{~cm}$.

\section{Percobaan Pendahuluan}

Percobaan pendahuluan yang digunakan pada penelitian ini meliputi pengamatan kondisi fisik dan kimia pada efluen reaktor Multi Soil Layering (MSL)

Percobaan ini ditujukan untuk mengetahui masa tunak dari reaktor, yaitu dimana kondisi saat reaktor sudah beradaptasi dan merupakan tahapan persiapan sebelum digunakan pada percobaan utama.

a. Pengamatan kondisi fisik

Berdasarkan Tabel 2 dan 3, pada 15 menit pertama belum stabil hasilnya hal ini diarenakan ketiga model reaktor masih belum terbiasa dengan limbah yang dialirkan, namun pada reaktor tahap pertama ketiga model reaktor mulai beradaptasi dengan air limbah pada 15 menit ke-4, sedangkan pada reaktor tahap kedua ketiga model reaktor mulai beradaptasi dengan air limbah pada 15 menit ke-3 hal ini ditunjukkan dengan adanya kondisi warna yang sama dan konstan. Warna yang telah sama dan konstan menujukkan bahwa ketiga reaktor telah dalam kondisi tunak. 
Tabel 2. Kondisi Efluen Reaktor Tahap 1

\begin{tabular}{|c|c|c|c|c|c|c|}
\hline \multirow{2}{*}{$\begin{array}{c}15 \text { menit } \\
\text { ke- }\end{array}$} & \multicolumn{2}{|c|}{ Zeolit } & \multicolumn{2}{c|}{ Kondisi Fisik } & \multicolumn{2}{c|}{ Zeolit dan Kerikil } \\
\cline { 2 - 7 } & Bau & Warna & Bau & Warna & Bau & Warna \\
\hline 1 & Berbau & $\begin{array}{c}\text { Bening } \\
\text { kecoklatan }\end{array}$ & Berbau & Kecoklatan & Berbau & $\begin{array}{c}\text { Bening } \\
\text { kecoklatan }\end{array}$ \\
\hline 2 & Berbau & $\begin{array}{c}\text { Bening } \\
\text { kecoklatan }\end{array}$ & Berbau & $\begin{array}{c}\text { Bening } \\
\text { kecoklatan }\end{array}$ & $\begin{array}{c}\text { Tidak } \\
\text { berbau }\end{array}$ & $\begin{array}{c}\text { Bening } \\
\text { kecoklatan }\end{array}$ \\
\hline 3 & Berbau & Bening & Berbau & $\begin{array}{c}\text { Bening } \\
\text { kecoklatan }\end{array}$ & $\begin{array}{c}\text { Tidak } \\
\text { berbau }\end{array}$ & $\begin{array}{c}\text { Bening } \\
\text { kecoklatan }\end{array}$ \\
\hline 4 & $\begin{array}{c}\text { Tidak } \\
\text { berbau }\end{array}$ & Bening & $\begin{array}{c}\text { Tidak } \\
\text { berbau }\end{array}$ & Bening & $\begin{array}{c}\text { Tidak } \\
\text { berbau }\end{array}$ & Bening \\
\hline 5 & $\begin{array}{c}\text { Tidak } \\
\text { berbau }\end{array}$ & Bening & $\begin{array}{c}\text { Tidak } \\
\text { berbau }\end{array}$ & Bening & $\begin{array}{c}\text { Tidak } \\
\text { berbau }\end{array}$ & Bening \\
\hline 6 & $\begin{array}{c}\text { Tidak } \\
\text { berbau }\end{array}$ & Bening & $\begin{array}{c}\text { Tidak } \\
\text { berbau }\end{array}$ & Bening & $\begin{array}{c}\text { Tidak } \\
\text { berbau }\end{array}$ & Bening \\
\hline
\end{tabular}

Tabel 3. Kondisi Efluen Reaktor Tahap 2

\begin{tabular}{|c|c|c|c|c|c|c|}
\hline \multirow{3}{*}{$\begin{array}{l}15 \text { menit } \\
\text { ke- }\end{array}$} & \multicolumn{6}{|c|}{ Kondisi Fisik } \\
\hline & \multicolumn{2}{|c|}{$\begin{array}{l}\text { Tanah andosol dan arang } \\
\text { aktif tempurung kelapa }\end{array}$} & \multicolumn{2}{|c|}{$\begin{array}{c}\text { Tanah andosol dan arang } \\
\text { sekam padi }\end{array}$} & \multicolumn{2}{|c|}{$\begin{array}{l}\text { Tanah andosol dan } \\
\text { serbuk gergaji }\end{array}$} \\
\hline & Bau & Warna & $\mathrm{Bau}$ & Warna & Bau & Warna \\
\hline 1 & Berbau & Bening & Berbau & $\begin{array}{c}\text { Bening } \\
\text { kecoklatan }\end{array}$ & Berbau & Bening \\
\hline 2 & $\begin{array}{c}\text { Tidak } \\
\text { berbau }\end{array}$ & Bening & $\begin{array}{l}\text { Tidak } \\
\text { berbau }\end{array}$ & $\begin{array}{c}\text { Bening } \\
\text { kecoklatan }\end{array}$ & $\begin{array}{l}\text { Tidak } \\
\text { berbau }\end{array}$ & Bening \\
\hline 3 & $\begin{array}{l}\text { Tidak } \\
\text { berbau }\end{array}$ & Bening & $\begin{array}{l}\text { Tidak } \\
\text { berbau }\end{array}$ & Bening & $\begin{array}{r}\text { Tidak } \\
\text { berbau }\end{array}$ & Bening \\
\hline 4 & $\begin{array}{l}\text { Tidak } \\
\text { berbau }\end{array}$ & Bening & $\begin{array}{c}\text { Tidak } \\
\text { berbau }\end{array}$ & Bening & $\begin{array}{l}\text { Tidak } \\
\text { berbau }\end{array}$ & Bening \\
\hline 5 & $\begin{array}{l}\text { Tidak } \\
\text { berbau }\end{array}$ & Bening & $\begin{array}{c}\text { Tidak } \\
\text { berbau }\end{array}$ & Bening & $\begin{array}{l}\text { Tidak } \\
\text { berbau }\end{array}$ & Bening \\
\hline 6 & $\begin{array}{l}\text { Tidak } \\
\text { berbau }\end{array}$ & Bening & $\begin{array}{l}\text { Tidak } \\
\text { berbau }\end{array}$ & Bening & $\begin{array}{l}\text { Tidak } \\
\text { berbau }\end{array}$ & Bening \\
\hline
\end{tabular}

b. Pengamatan kondisi kimia

Dari Tabel 4 dan Tabel 5 dapat dilihat pada 15 menit pengambilan pertama masih mengalami fluktuasi karena limbah dalam masa penyesuaian dengan reaktor, ketika 15 menit 4 nilai $\mathrm{Ph}$ dan $\mathrm{DO}$ yang dihasilkan semakin meningkat menunjukkan bahwa reaktor dalam kondisi tunak. Dimana kondisi yang menyatakan reaktor telah siap untuk dialiri air limbah domestik.

Tabel 4. Kondisi fisik kimia efluen reaktor pertama

\begin{tabular}{|l|c|c|c|c|c|c|}
\hline \multicolumn{1}{|c|}{15 menit ke- } & 1 & 2 & 3 & 4 & 5 & 6 \\
\hline pH zeolit & \multicolumn{7}{|c|}{$\mathrm{pH}$ awal 6,42} \\
\hline $\mathrm{pH}$ kerikil & 7,18 & 7,34 & 7,25 & 7,31 & 7,38 & 7,15 \\
\hline $\mathrm{pH}$ zeolit dan kerikil & 7,21 & 7,33 & 7,31 & 7,25 & 7,28 & 7,30 \\
\hline \multicolumn{7}{|c|}{ DO awal $0,69 \mathrm{mg} / 1$} \\
\hline DO zeolit & 7,16 & 7,34 & 7,22 & 7,31 & 7,35 & 7,39 \\
\hline DO kerikil & 2,12 & 2,22 & 2,16 & 2,32 & 3,50 & 3,62 \\
\hline DO zeolit dan kerikil & 1,21 & 1,81 & 2,17 & 2,69 & 3,22 & 3,39 \\
\hline
\end{tabular}


Tabel 5. Kondisi fisik kimia efluen reaktor kedua

\begin{tabular}{|c|c|c|c|c|c|c|}
\hline 15 menit ke- & 1 & 2 & 3 & 4 & 5 & 6 \\
\hline \multicolumn{7}{|l|}{ pH awal 6,68 } \\
\hline $\begin{array}{l}\text { pH zeolit dengan isian tanah andosol dengan arang aktif } \\
\text { tempurung kelapa }\end{array}$ & 6,91 & 6,89 & 6,83 & 6,85 & 7,15 & 6,88 \\
\hline pH Zeolit dengan isian tanah andosol dengan arang sekam padi & 6,84 & 6,80 & 6,81 & 6,83 & 6,99 & 7,00 \\
\hline pH Zeolit dengan isian tanah andosol dengan serbuk gergaji & 6,81 & 6,79 & 6,79 & 6,80 & 6,88 & 6,89 \\
\hline \multicolumn{7}{|l|}{ DO awal $1,99 \mathrm{mg} / \mathrm{l}$} \\
\hline $\begin{array}{l}\text { DO zeolit dengan isian tanah andosol dengan arang aktif } \\
\text { tempurung kelapa }\end{array}$ & 3,74 & 3,86 & 3,41 & 4,23 & 4,40 & 4,46 \\
\hline $\begin{array}{l}\text { DO Zeolit dengan isian tanah andosol dengan arang sekam } \\
\text { padi }\end{array}$ & 3,33 & 2,69 & 2,61 & 3,42 & 3,74 & 3,76 \\
\hline DO Zeolit dengan isian tanah andosol dengan serbuk gergai & 3,03 & 3,84 & 3,18 & 3,94 & 4,12 & 4,27 \\
\hline
\end{tabular}

\section{Percobaan Utama}

\section{Derajat Keasaman (pH)}

Limbah yang akan diuji dilakukan pengukuran $\mathrm{pH}$ sebelum dan sesudah melewati reaktor MSL, bertujuan untuk mengetahui apakah ada perbuahan nilai dan menentukan efisiensi alat dalam mengolah limbah domestik Kelurahan Tlogomas.

Konsentrasi $\mathrm{pH}$ awal sebelum diolah sebesar 6,60. Setelah mengalami proses pengolahan pada reaktor MSL tahap pertama, secara keseluruhan mengalami kenaikan sebesar 6,84 - 7,26. Nilai konsentrasi $\mathrm{pH}$ pada tahap pertama masih berada dalam standar baku mutu 6,0-9,0 (Gambar 4).

Dari Gambar 5 didapatkan bahwa hasil pada tahap pertama dari ketiga reaktor mampu menaikkan konsentasi $\mathrm{pH}$ sebesar
$3,46 \%-9,13 \%$. Hal ini dipengaruhi proses netralisasi muatan negatif karbon oleh ionion nitrogen pada zeolit.

Konsentrasi $\mathrm{pH}$ sebelum diolah adalah 6,70 . Setelah mengalami proses pengolahan nilai $\mathrm{pH}$ mengalami kenaikan sebesar 6,737,11 . Nilai konsentrasi $\mathrm{pH}$ pada tahap kedua masih berada dalam standar baku mutu 6,09,0 (Gambar 6).

Pada reaktor tahap kedua isian zeolite tanah dan arang tempurung kelapa, zeolite tanah dan serbuk gergaji, zeolite tanah dan jerami padi secara keseluruhan mengalami kenaikan prosentase sebesar $0,48 \%-6,03 \%$. Kenaikan nilai $\mathrm{pH}$ tersebut dipengaruhi karena proses netralisasi muatan negatif karbon oleh ion-ion nitrogen pada zeolite (Gambar 7).

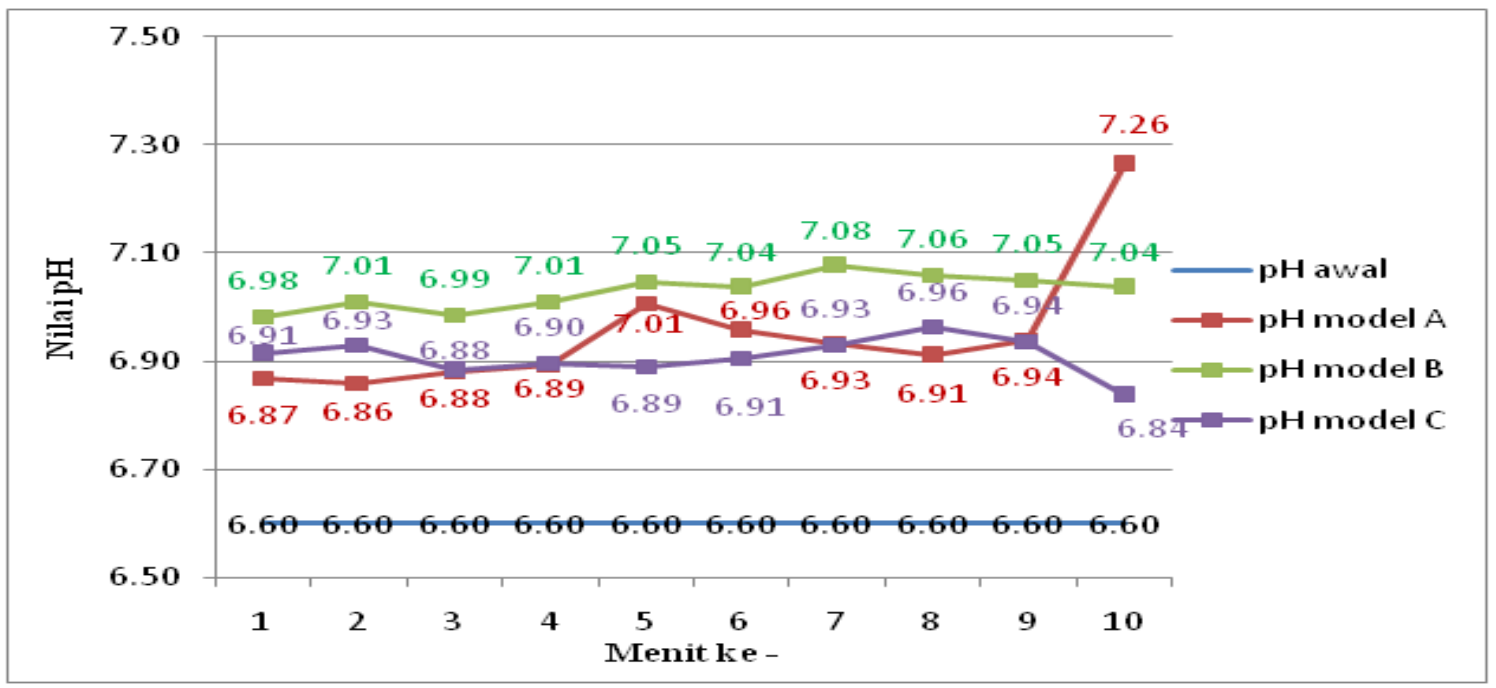

Gambar 4. Grafik nilai $\mathrm{pH}$ 


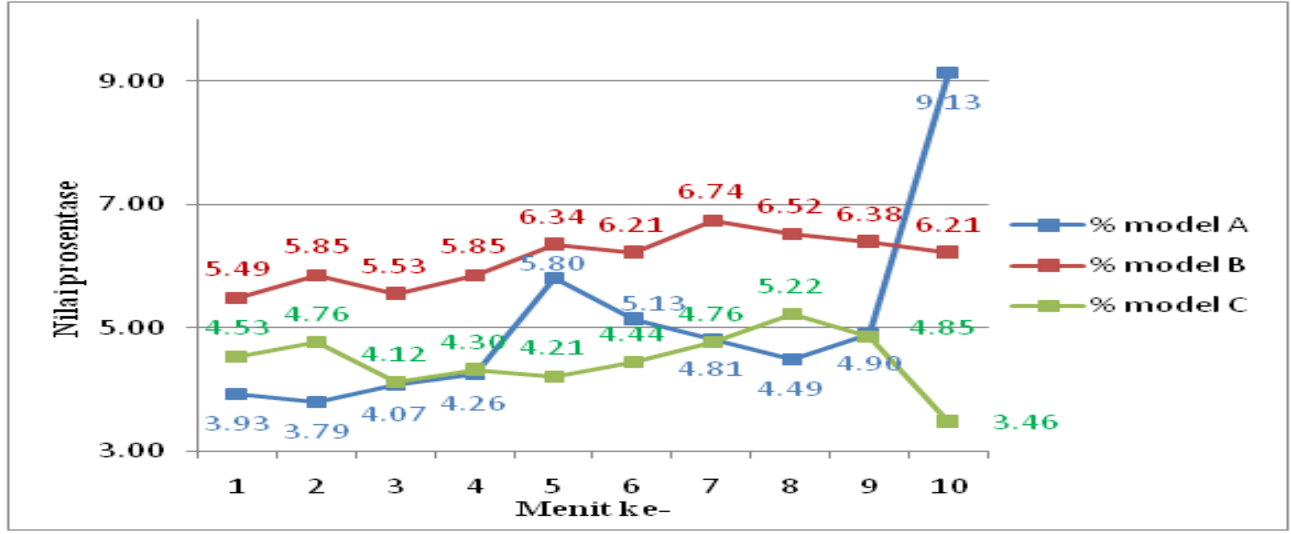

Gambar 5. Grafik prosentase kenaikan nilai pH air terhadap pH awal

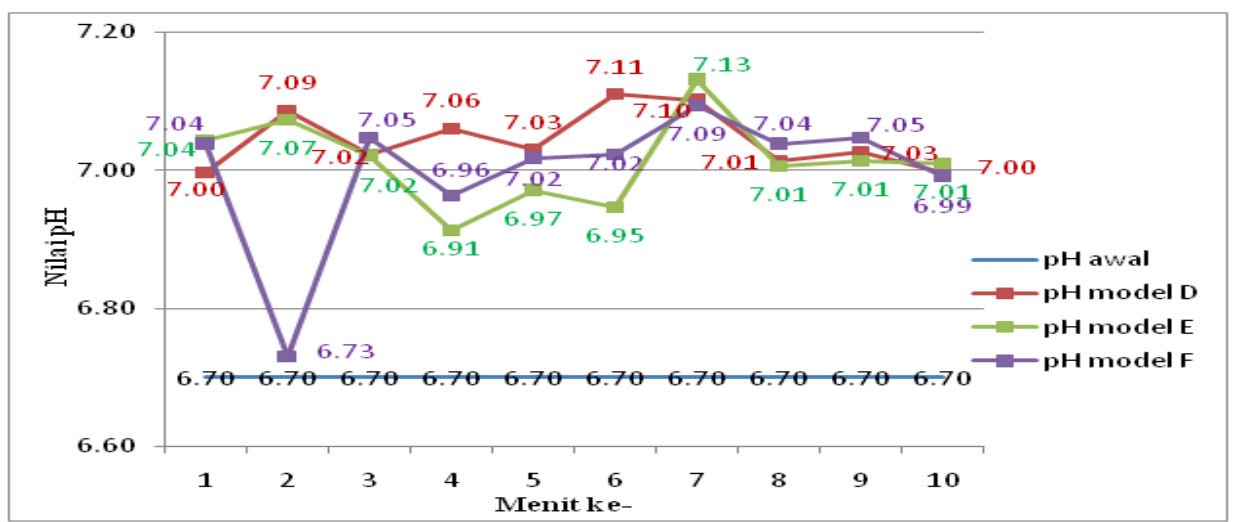

Gambar 6. Grafik nilai $\mathrm{pH}$

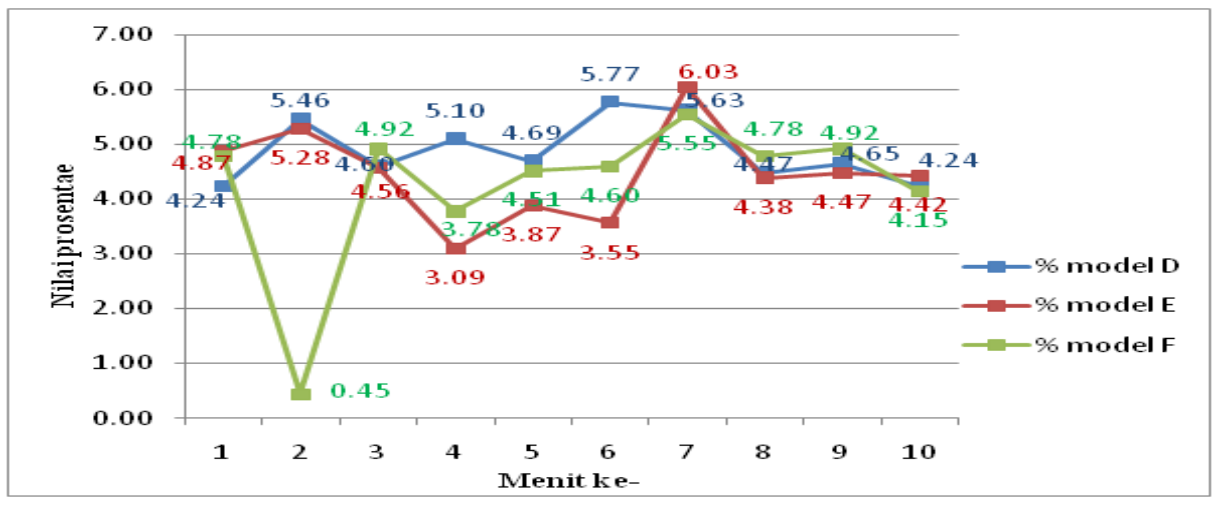

Gambar 7. Grafik prosentase kenaikan nilai $\mathrm{pH}$ air terhadap $\mathrm{pH}$ awal

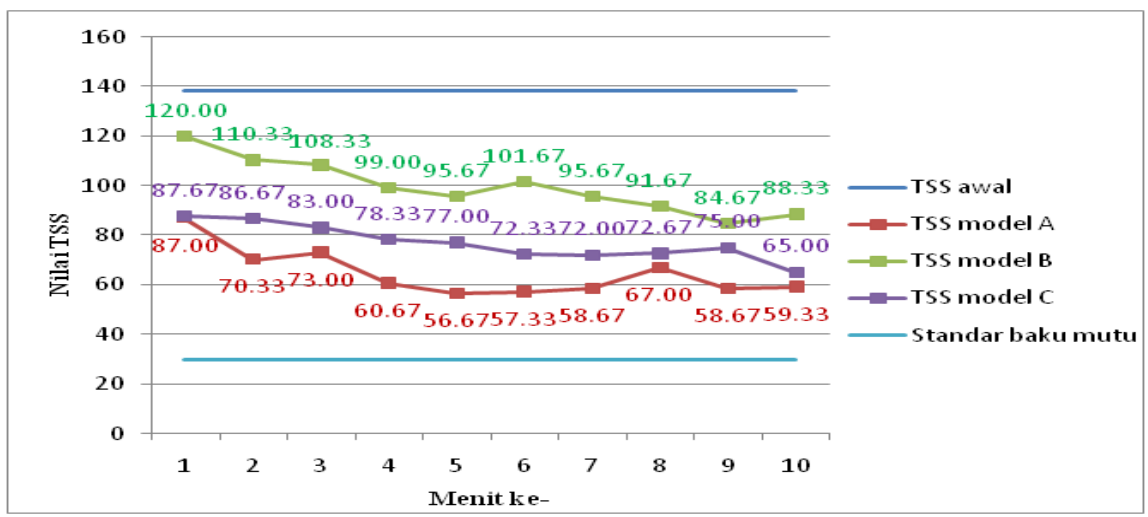

Gambar 8. Grafik nilai TSS 


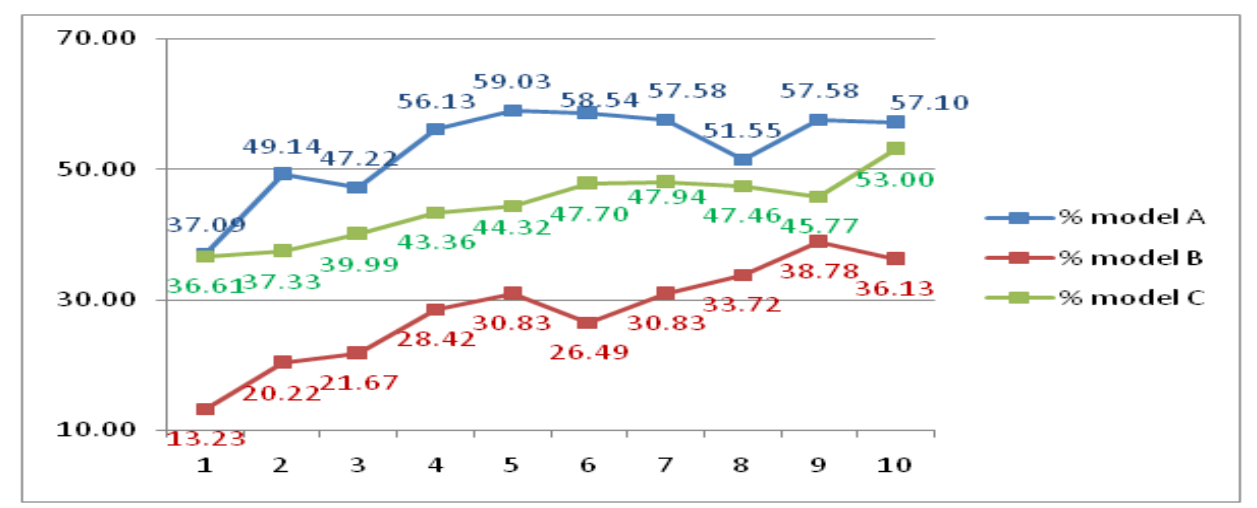

Gambar 9. Grafik prosentase penurunan nilai TSS air terhadap TSS awal

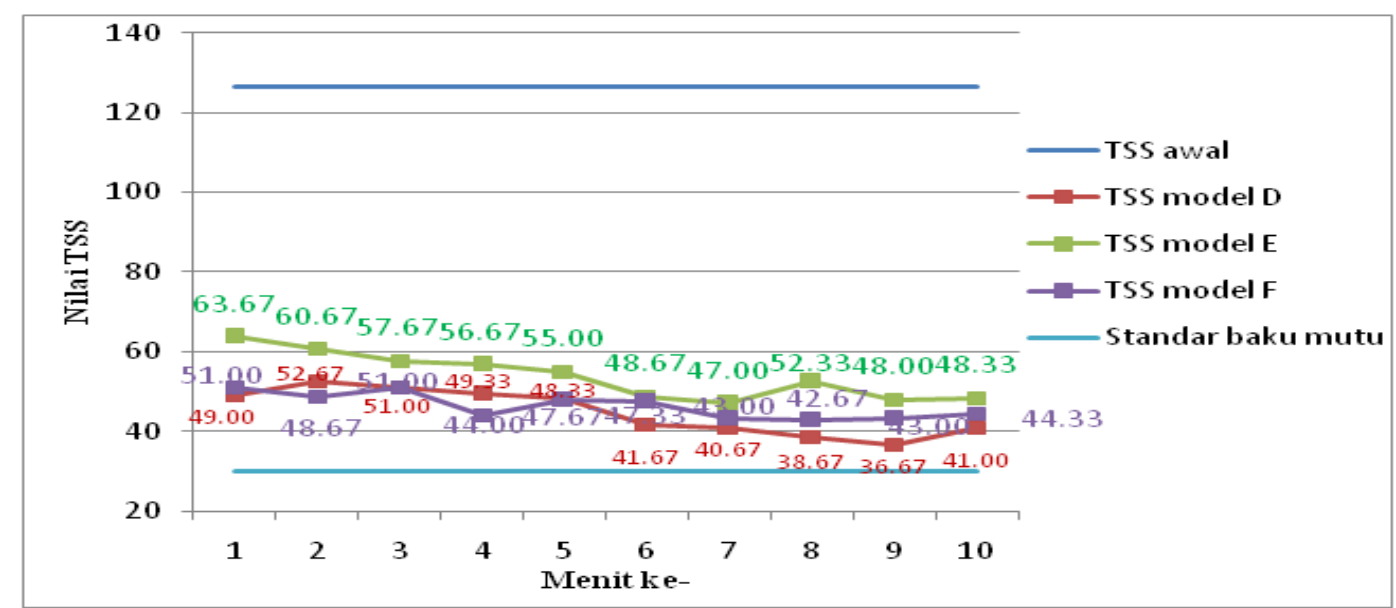

\section{Gambar 10. Grafik nilai TSS}

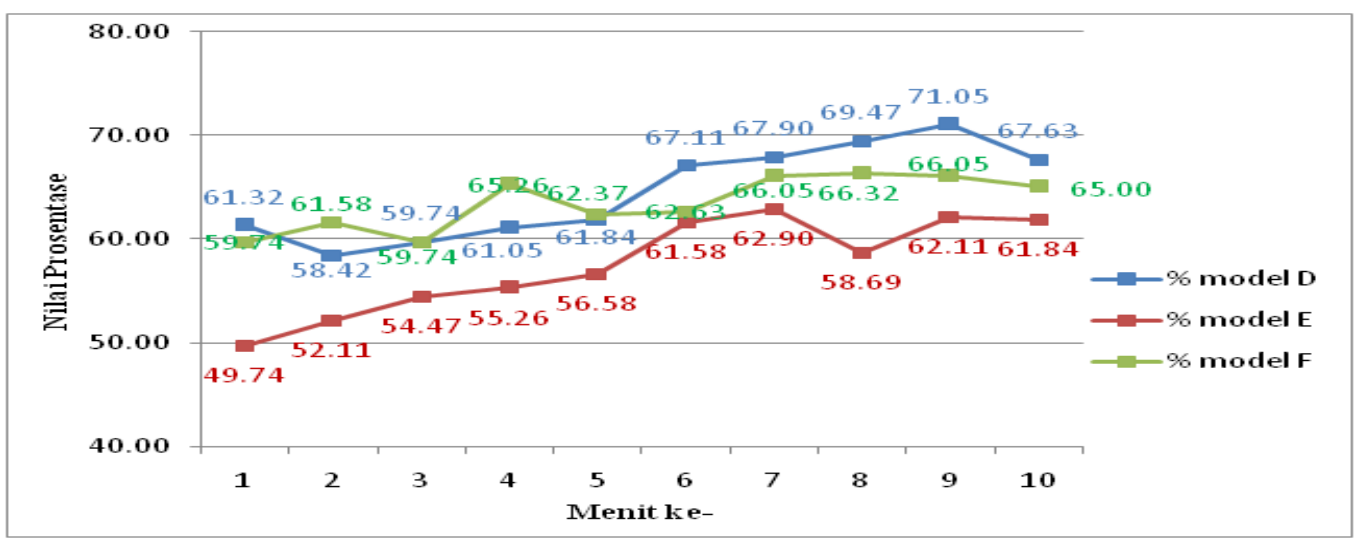

Gambar 11. Grafik prosentase penurunan nilai TSS air terhadap TSS awal

\section{Total Suspended Solid (TSS)}

Pengukuran TSS sebelum dan sesudah melewati reaktor MSL, bertujuan untuk mengetahui apakah ada perubahan nilai dan menentukan efisiensi alat Metode Multi Soil Layering (MSL) dalam mengolah limbah domestik yang ada di Kelurahan Tlogomas.

Konsentrasi TSS awal sebesar 138,3 $\mathrm{mg} / \mathrm{L}$. setelah mengalami proses pengolahan pada reaktor MSL tahap pertama dari ketiga reaktor secara keseluruhan mengalami penurunan sebesar $56,67-120,00 \mathrm{mg} / \mathrm{l}$.
Penurunan nilai TSS ini dikarenakan adanya kerikil sebagai penyaring molekul yang berukuran besar dan kemampuan zeolite sebagai adsorben (Gambar 8). Dari Gambar 9 didapatkan hasil bahwa pada reaktor tahap pertama dengan isian zeolite, kerikil, dan campuran kerikil dan zeolite secara keseluruhan mampu menurunkan prosentase TSS sebesar 13,23\%-59,03\%.

Konsentrasi nilai TSS sebelum diolah adalah 126,67 mg/L. Setelah mengalami proses pengolahan tahap kedua dengan isian 
zeolite tanah dan arang tempurung kelapa, zeolite tanah dan serbuk gergaji, zeolite tanah dan jerami padi secara keseluruhan nilai TSS mengalami penurunan sebesar 36,67-52,67 $\mathrm{mg} / \mathrm{l}$ (Gambar 10). Penurunan nilai TSS ini dikarenakan sifat zeolite sebagai adsorben, besarnya daya serap yang dimiliki serbuk gergaji dan kandungan silika yang dimiliki arang sekam padi berfungsi sebagai penyaring kotoran berukuran kecil yang terbawa air. Dari Gambar 11 didapatkan hasil bahwa pada reaktor tahap kedua dengan isian zeolite tanah dan arang tempurung kelapa, zeolite tanah dan serbuk gergaji, zeolite tanah dan jerami padi secara keseluruhan mampu menurunkan prosentase TSS sebesar 49,74\% $-71,05 \%$.

\section{Total Dissolved Solid (TDS)}

Limbah yang akan diuji dilakukan pengukuran TDS sebelum dan sesudah melewati reaktor MSL, bertujuan untuk mengetahui apakah ada perubahan nilai dan menentukan efisiensi alat Metode Multi Soil Layering (MSL) dalam mengolah limbah domestik yang ada di kelurahan Tlogomas. TDS yang dijadikan tolok ukur penentuan hasil kerja reaktor memiliki standar baku mutu $1500 \mathrm{mg} / \mathrm{L}$.

Konsentrasi TDS sebelum diolah adalah $541,33 \mathrm{mg} / \mathrm{L}$. Setelah mengalami proses pengolahan pada reaktor MSL pertama untuk reaktor dengan isian zeolite, kerikil, dan campuran zeolite dan kerikil secara keseluruhan mampu menurunkan nilai TDS sebesar 454,33 - 526,67 mg/L (Gambar 12). Penurunan nilai TDS ini dikarenakan adanya kerikil sebagai penyaring molekul yang berukuran besar dan kemampuan zeolite sebagai adsorben.

Dari Gambar 13 didapatkan hasil bahwa pada reaktor tahap pertama dengan isian zeolite, kerikil, dan campuran kerikil dan zeolite secara keseluruhan mampu menurunkan prosentase TDS sebesar $2,77 \%$ $16,07 \%$.

Konsentrasi TDS awal adalah $602 \mathrm{mg} / \mathrm{L}$ (Gambar 14). Setelah mengalami proses pengolahan pada tahap kedua dengan isian zeolite tanah dan arang tempurung kelapa, zeolite tanah dan serbuk gergaji, zeolite tanah dan jerami padi, secara keseluruhan nilai TSS mengalami penurunan sebesar 396,00 497,00 mg/l. Penurunan nilai TDS ini dikarenakan sifat zeolite sebagai adsorben, besarnya daya serap yang dimiliki serbuk gergaji, kandungan silika yang dimiliki arang sekam padi berfungsi sebagai penyaring kotoran berukuran kecil yang terbawa air limbah serta sifat karbon yang dimiliki arang aktif mampu menyerap polutan yang terkandung dalam air limbah. Sedangkan pada reaktor tahap kedua dengan isian zeolite tanah dan arang tempurung kelapa, zeolite tanah dan serbuk gergaji, zeolite tanah dan jerami padi secara keseluruhan mampu menurunkan prosentase TDS sebesar 14,01\% - 34,22\% (Gambar 15).

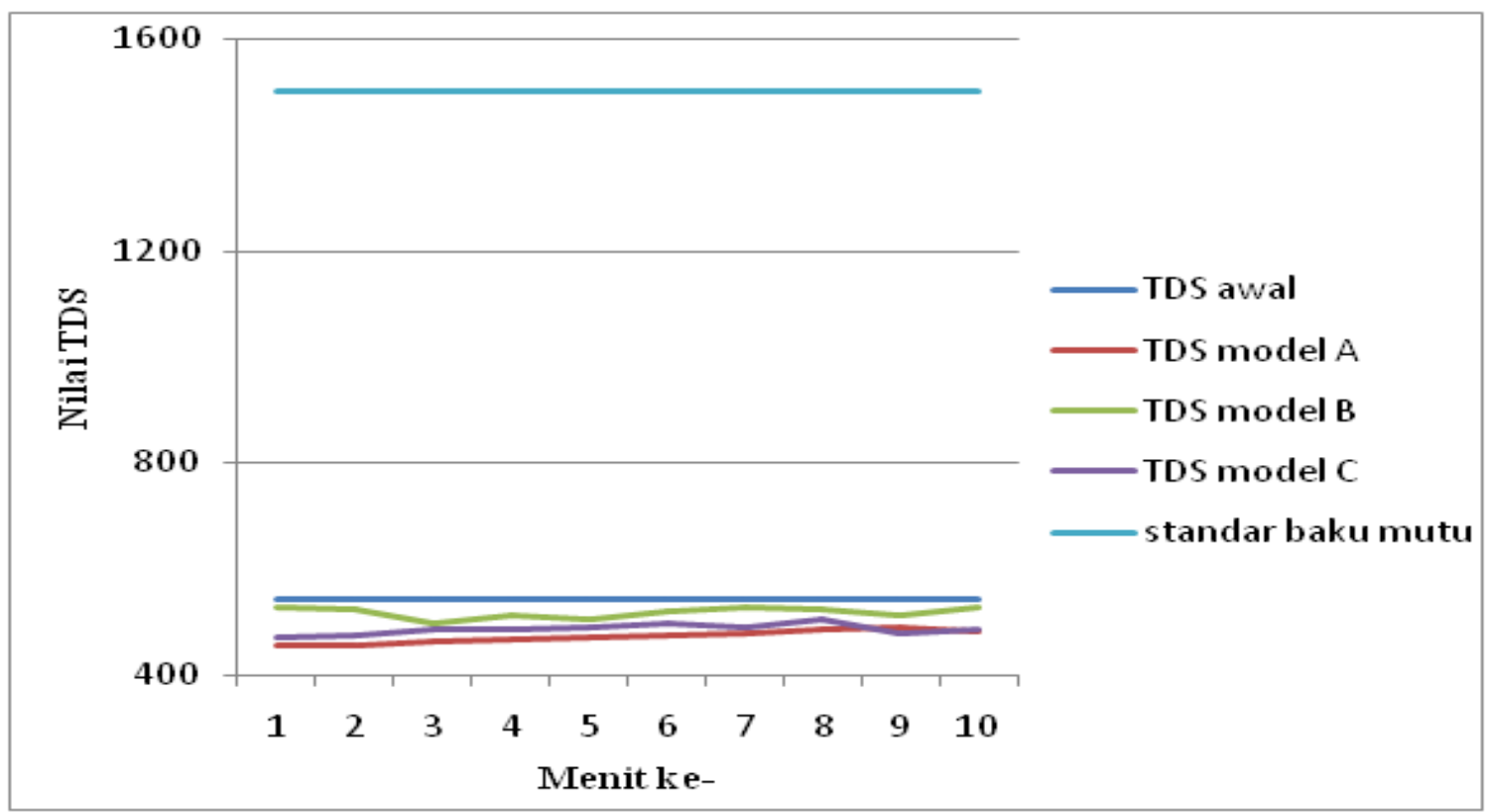

Gambar 12. Grafik nilai TDS 


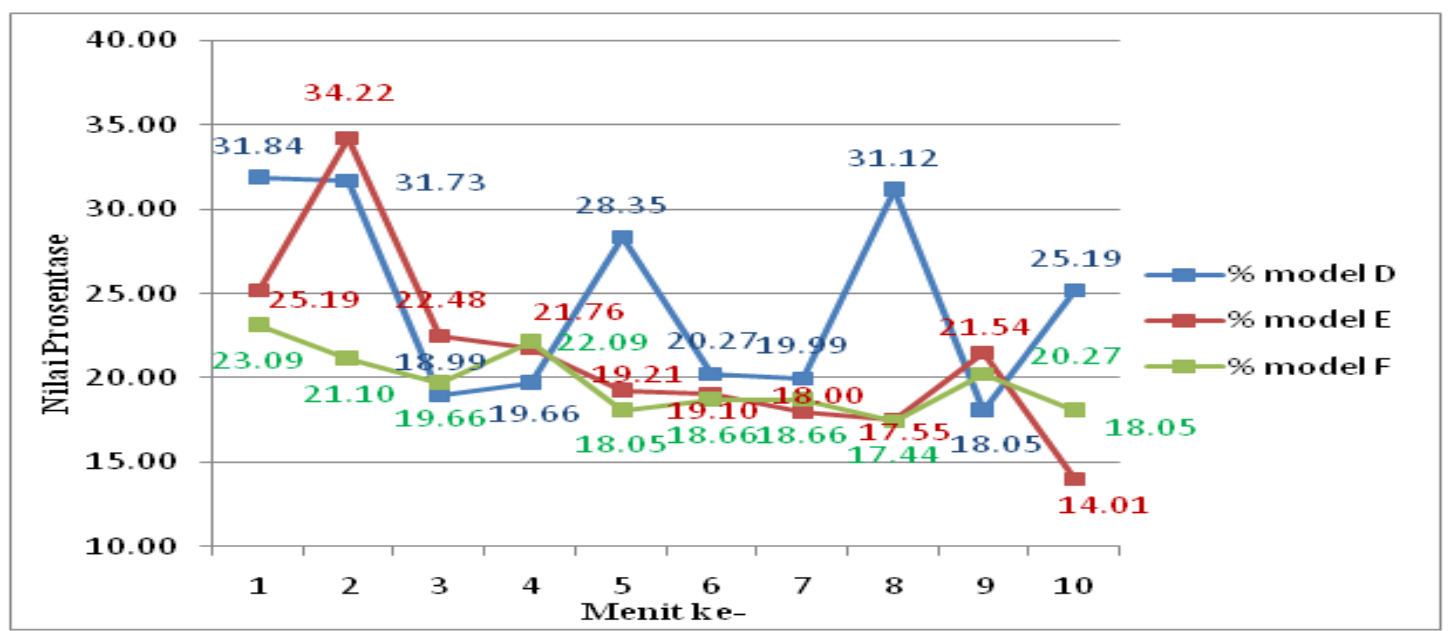

Gambar 13. Grafik prosentase penurunan nilai TDS air terhadap TDS awal

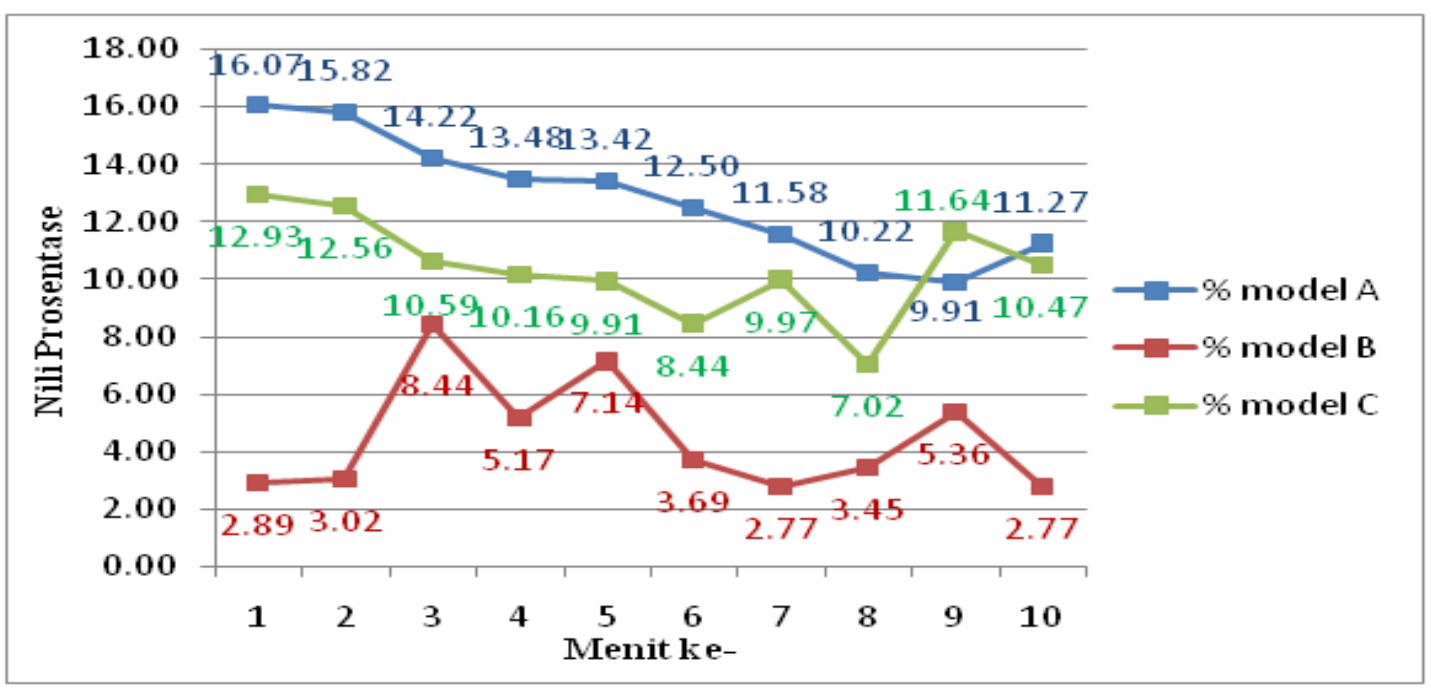

Gambar 14. Grafik nilai TDS

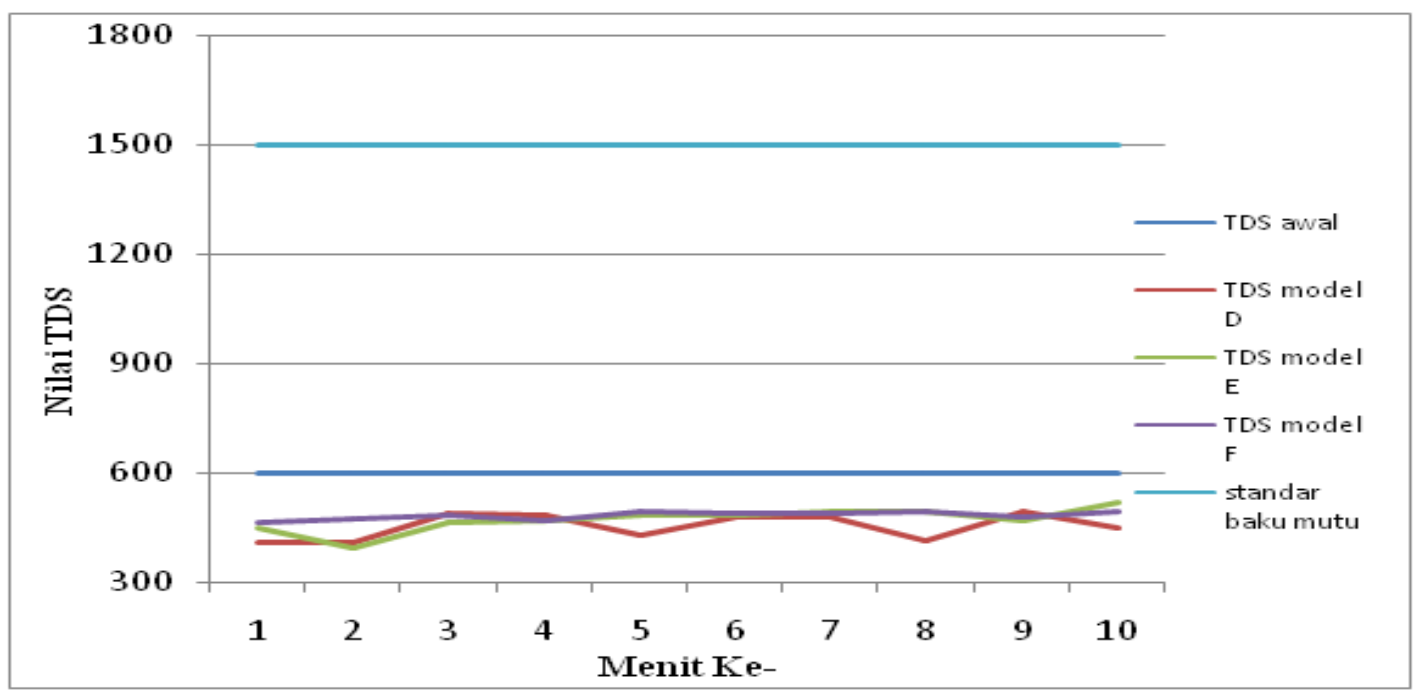

Gambar 15. Grafik prosentase penurunan nilai TDS air terhadap TDS awal 


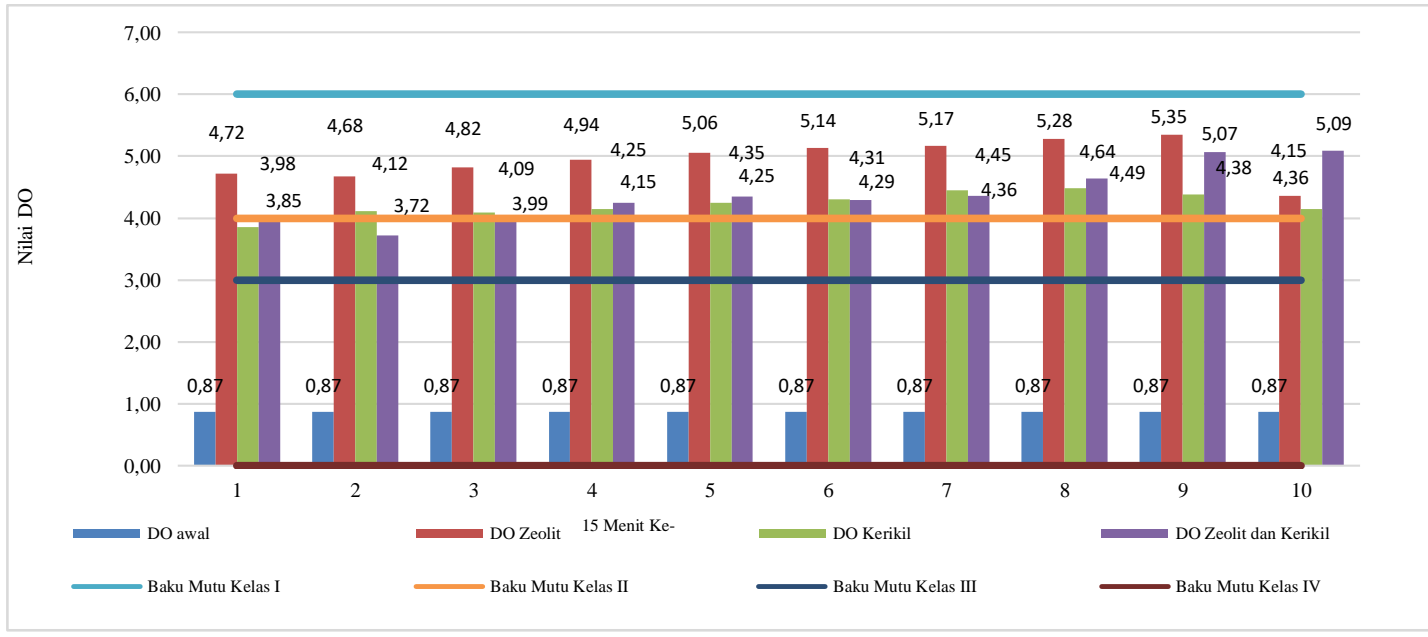

Gambar 16. Grafik Nilai Dissolved Oxygen

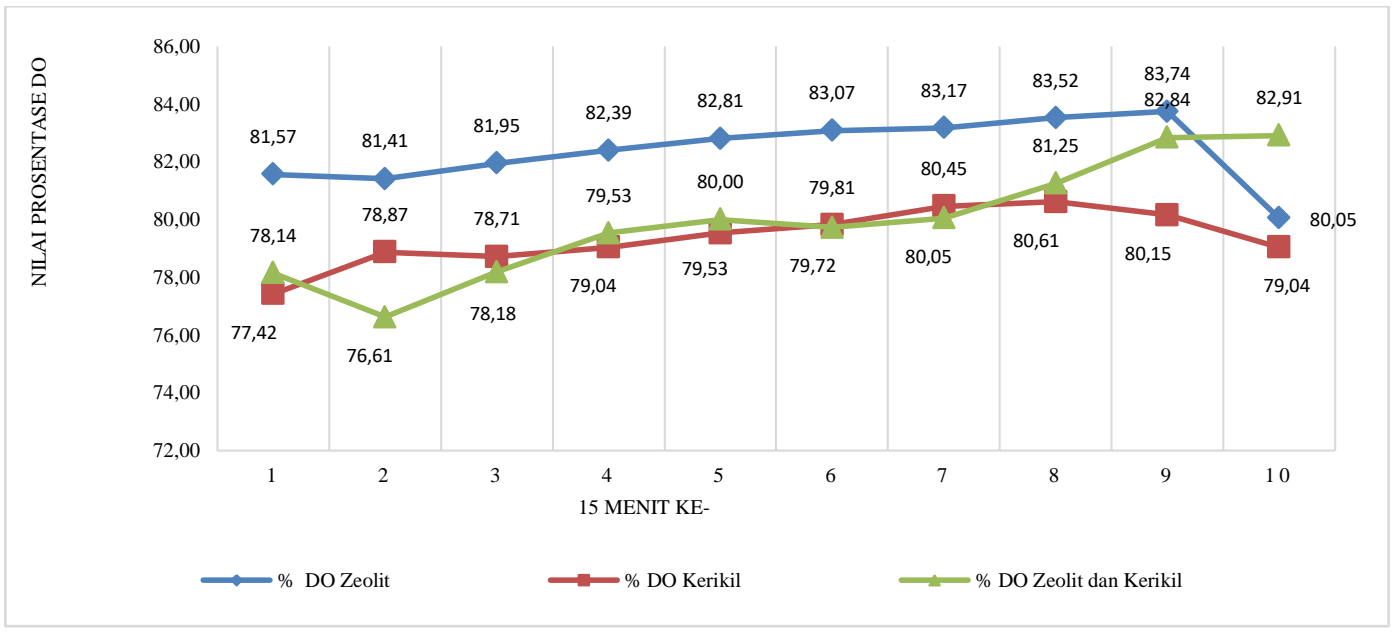

Gambar 17. Grafik prosentase kenaikan nilai Dissolved Oxygen

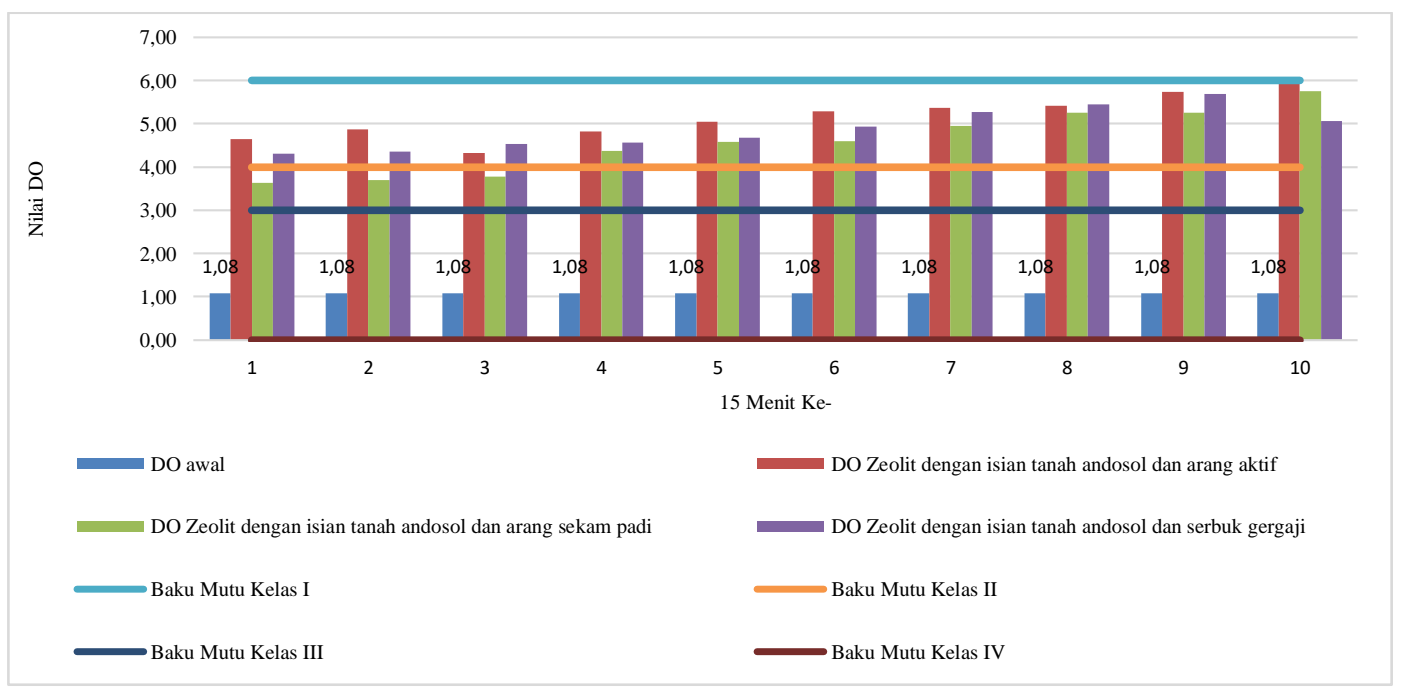

Gambar 18. Grafik Nilai Dissolved Oxygen 


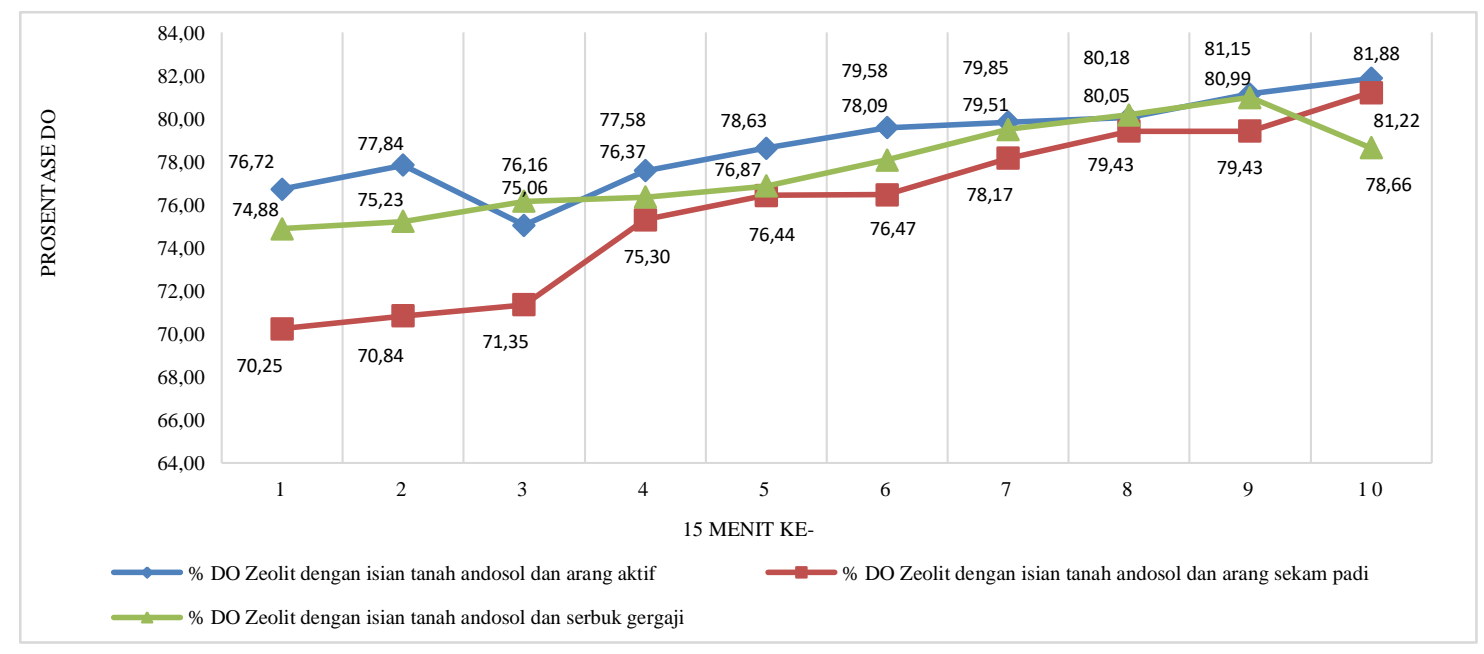

Gambar 19. Grafik prosentase kenaikan nilai Dissolved Oxygen (DO)

\section{Dissolved Oxygen (DO)}

Pengukuran kandungan oksigen terlarut dilakukan sebelum pengolahan dan setelah pengolahan air. Hal ini bertujuan untuk mengetahui besarnya efisiensi kenaikan jumlah oksigen terlarut dalam air limbah yang terdapat di MCK Terpadu Tlogomas.

Nilai awal air limbah sebelum melalui reaktor MSL memiliki nilai DO sebesar 0,87 $\mathrm{mg} / \mathrm{L}$. Setelah diolah dengan menggunakan metode MSL tahap pertama secara keseluruhan nilai DO mengalami kenaikan sebesar 3,72 - 5,35 mg/L (Gambar 16). Kenaikan nilai DO diatas dikarenakan adanya kontak langsung antara air limbah dengan udara.

Dari Gambar 17 didapatkan hasil prosentase kenaikan DO pada percobaan pertama untuk reaktor dengan isian zeolit, kerikil, dan campuran zeolit dan kerikil sebesar 76,61\% - 83,74\%.

Nilai DO awal sebelum melalui reaktor MSL sebesar 1,08 mg/L (Gambar 18). Setelah melalui proses pengolahan, secara keseluruhan nilai DO mengalami kenaikan sebesar 3,63 - 5,96 mg/L. Kenaikan nilai DO diatas dikarenakan adanya kontak langsung antara air limbah dengan udara.

Gambar 19 menunjukkan hasil prosentase yang didapat pada pengukuran DO percobaan kedua untuk reaktor dengan isian zeolite tanah dan arang tempurung kelapa, zeolite tanah dan serbuk gergaji, zeolite tanah dan jerami padi secara keseluruhan mampu menurunkan prosentase TDS sebesar 70,25\% - 81,88\%.

\section{Kekeruhan}

Pengukuran kandungan kekeruhan dilakukan sebelum pengolahan dan setelah pengolahan air limbah menggunakan metode MSL. Hal ini bertujuan untuk mengetahui besarnya efisiensi penurunan padatan tersuspensi dalam air limbah yang terdapat di MCK Terpadu Tlogomas.

Nilai awal kekeruhan sebesar 489 NTU (Gambar 20). Setelah diolah menggunakan metode MSL secara keseluruhan nilai kekeruhan mengalami penurunan sebesar 163 - 255 NTU. Penurunan tersebut dikarenakan adanya kerikil sebagai penyaring partikel tersuspensi yang berukuran besar, selain itu zeolit juga berpengaruh terhadap penurunan kekeruhan karena mampu menyerap partikel koloid.

Hasil prosentase yang didapat pada pengukuran parameter kekeruhan percobaan pertama untuk reaktor dengan isian zeolit, kerikil dan campuran kerikil zeolit rata rata memiliki prosentase penurunan sebesar 47,82\% - 67,85\% (Gambar 21).

Nilai awal dan nilai kekeruhan sebesar 502 NTU. Setelah diolah menggunakan metode MSL secara keseluruhan nilai kekeruhan mengalami penurunan. Reaktor dengan isian zeolite tanah dan arang tempurung kelapa, zeolite tanah dan serbuk gergaji, zeolite tanah dan jerami padi secara keseluruhan mampu menurunkan kekeruhan sebesar 113 - 152 NTU (Gambar 22). Penurunan tersebut terjadi karena padatan tersuspensi sebagian besar terserap oleh zeolite, serbuk gergaji dan arang aktif. 
Gambar 23 menunjukkan hasil prosentase yang didapat pada pengukuran parameter kekeruhan percobaan kedua untuk reaktor dengan isian zeolite tanah dan arang tempurung kelapa, zeolite tanah dan serbuk gergaji, zeolite tanah dan jerami padi secara keseluruhan memiliki prosentase sebesar $69,72 \%-77,49 \%$
Daya Hantar Listrik (DHL)

Pengukuran kandungan daya hantar listrik dilakukan sebelum pengolahan dan setelah pengolahan air limbah menggunakan metode MSL. Hal ini bertujuan untuk mengetahui besarnya efisiensi penurunan nilai daya hantar listrik dalam air limbah yang terdapat di MCK Terpadu Tlogomas.

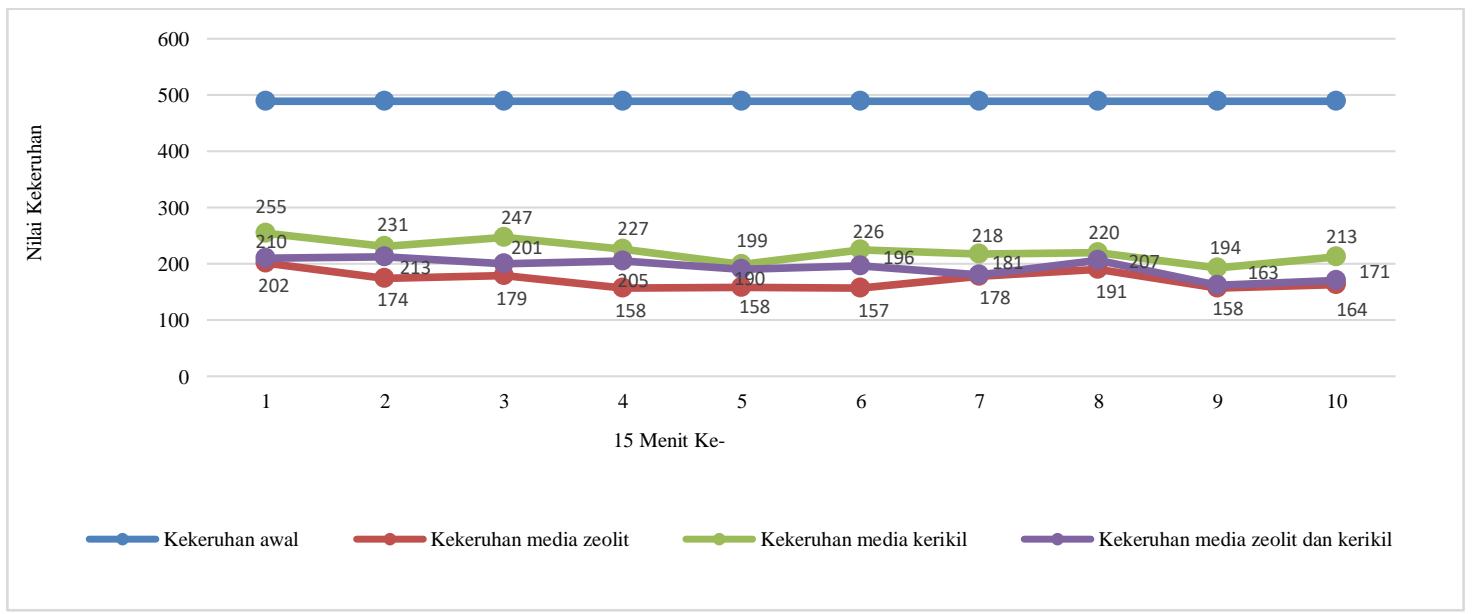

Gambar 20. Grafik Nilai Kekeruhan

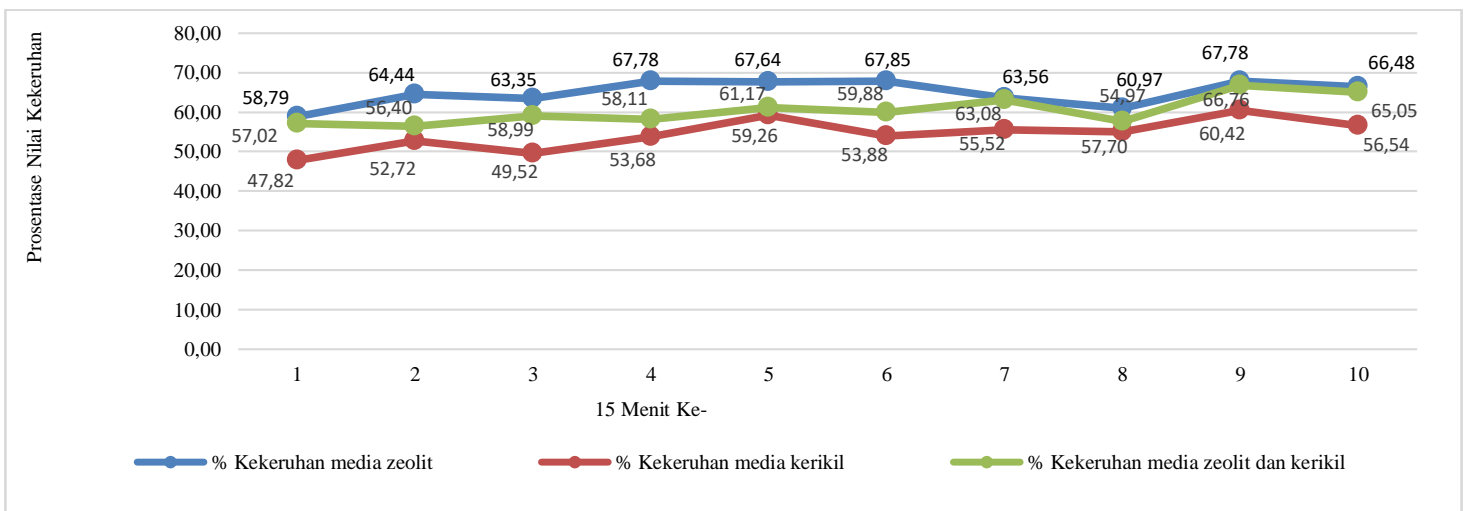

Gambar 21. Grafik Prosentase Penurunan Nilai Kekeruhan

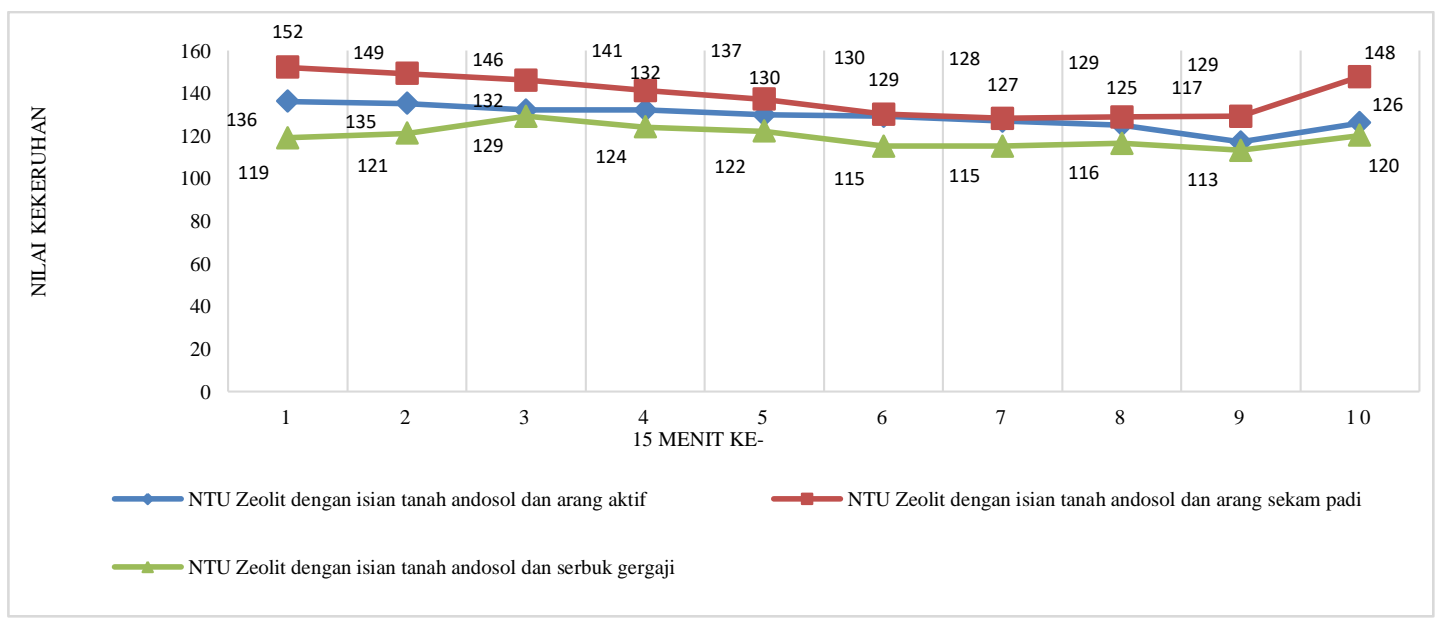

Gambar 22. Grafik Nilai Kekeruhan 


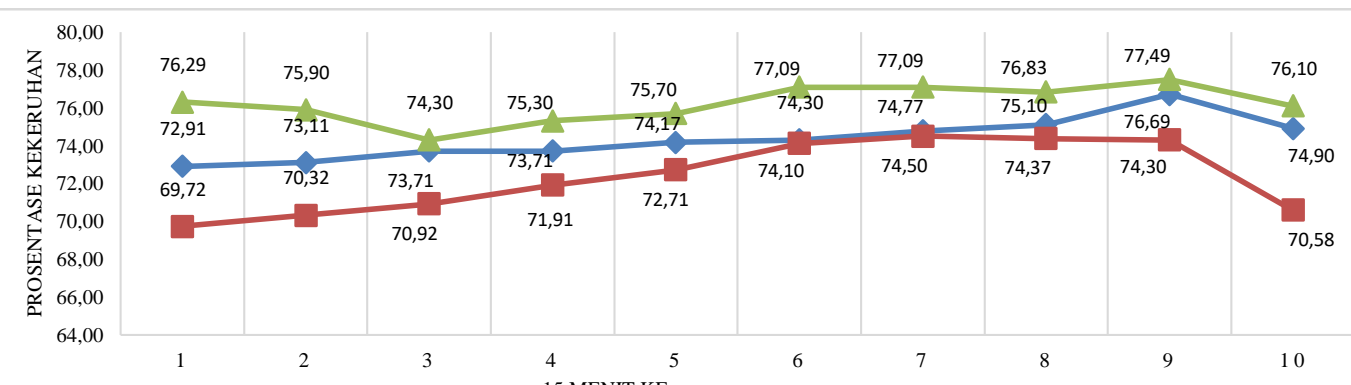
15 MENIT KE-

$\%$ NTU Zeolit dengan isian tanah andosol dan arang aktif - $\%$ NTU Zeolit dengan isian tanah andosol dan arang sekam padi _ $\%$ NTU Zeolit dengan isian tanah andosol dan serbuk gergaji

Gambar 23. Grafik Prosentase Penurunan Nilai Kekeruhan

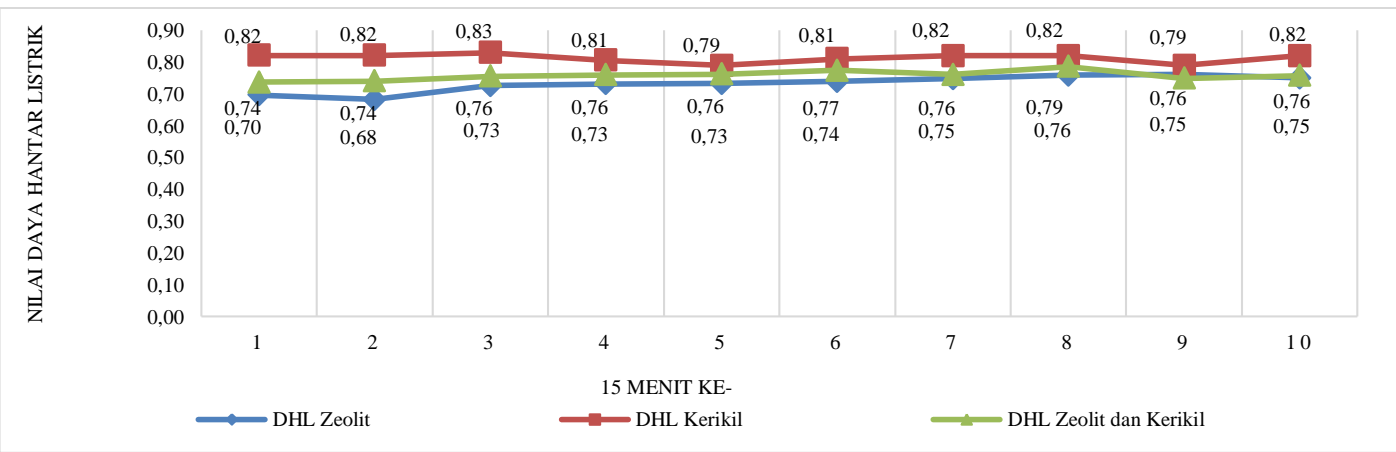

Gambar 24. Grafik Nilai Daya Hantar Listrik

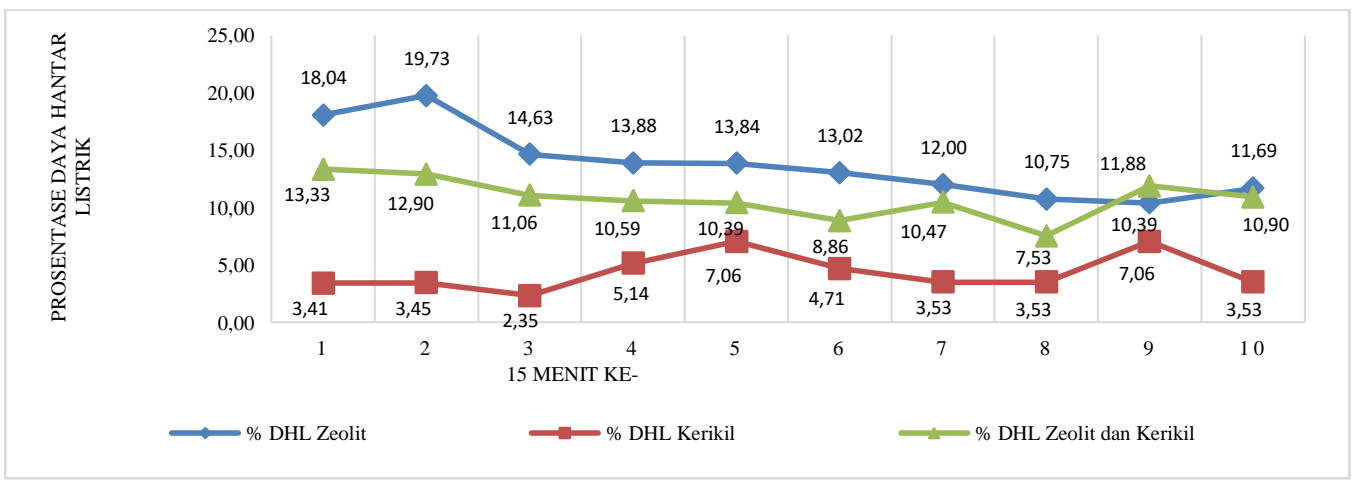

Gambar 25. Grafik Prosentase Penurunan Nilai Daya Hantar Listrik

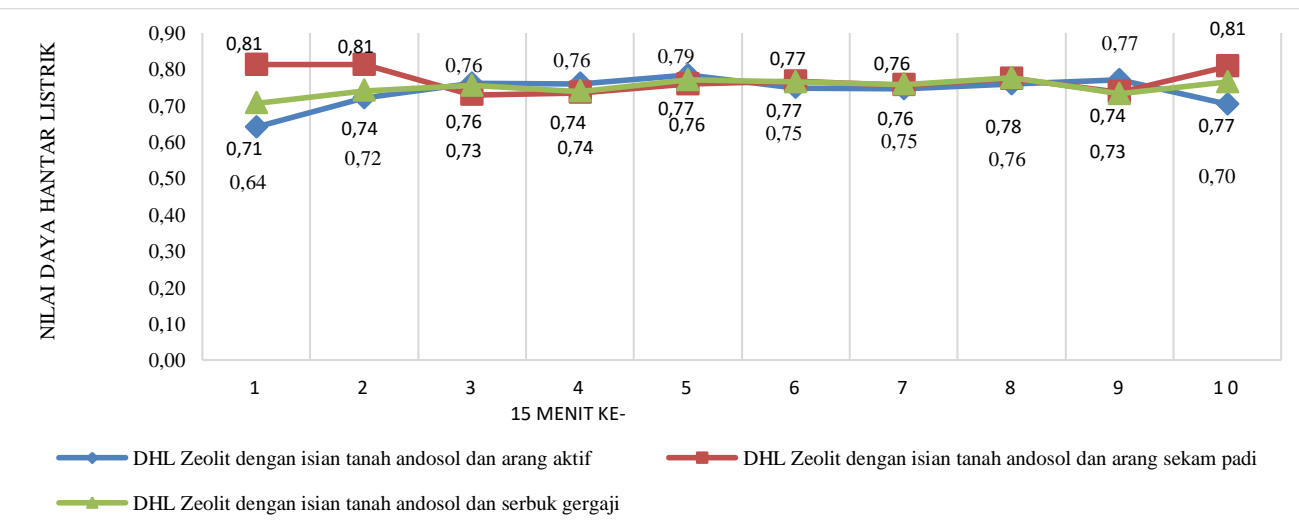

Gambar 26. Grafik Nilai Daya Hantar Listrik 


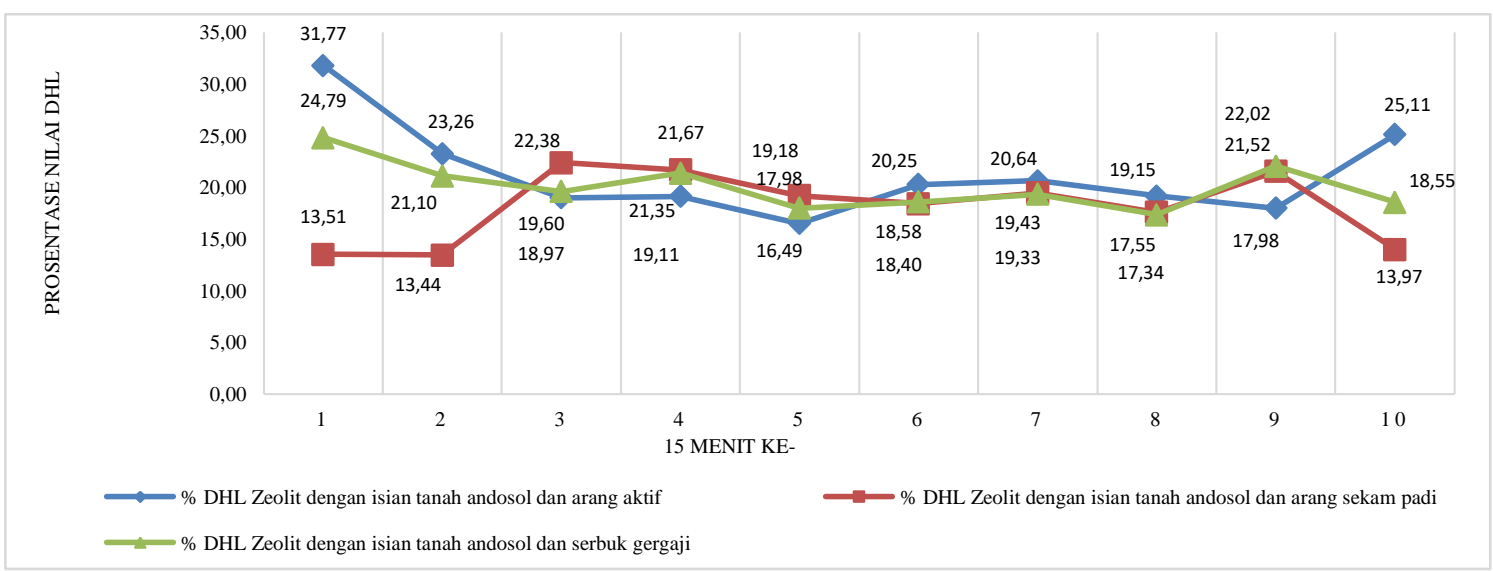

Gambar 27. Grafik Prosentase Penurunan Nilai Daya Hantar Listrik

Nilai awal daya hantar listrik sebesar $0,85 \mathrm{mS} / \mathrm{cm}$. Setelah diolah nilai DHL mengalami penurunan. Reaktor dengan isian zeolit, kerikil dan campuran kerikil zeolit mengalami penurunan sebesar $0,68-0,83$ $\mathrm{mS} / \mathrm{cm}$ (Gambar 24). Penurunan tersebut dikarenakan sifat zeolit sebagai penukar ion.

Hasil prosentase yang didapat pada pengukuran parameter daya hantar listrik percobaan pertama reaktor dengan isian zeolit, kerikil, campuran zeolit dan kerikil memiliki prosentase penurunan kekeruhan sebesar 2,35\% - 19,73\% (Gambar 25).

Nilai awal daya hantar listrik sebesar 0,94 $\mathrm{mS} / \mathrm{cm}$. Setelah diolah nilai DHL mengalami penurunan. Reaktor dengan isian zeolite tanah dan arang tempurung kelapa, zeolite tanah dan serbuk gergaji, zeolite tanah dan jerami padi secara keseluruhan mampu menurunkan nilai daya hantar listrik sebesar 0,64 - 0,81 mS/cm (Gambar 26). Penurunan tersebut dikarenakan sifat zeolit sebagai penukar ion selain itu nilai daya hantar listrik juga dipengaruhi oleh $\mathrm{pH}$. Semakin $\mathrm{pH}$ bersifat asam maka nilai DHL semakin tinggi sedangkan semakin $\mathrm{pH}$ bersifat basa maka nilai DHL semakin rendah.

Hasil prosentase yang didapat pada pengukuran parameter daya hantar listrik percobaan kedua untuk reaktor dengan isian zeolite tanah dan arang tempurung kelapa, zeolite tanah dan serbuk gergaji, zeolite tanah dan jerami padi secara keseluruhan memiliki prosentase daya hantar listrik sebesar 13,44\% - 31,77\% (Gambar 27).

\section{Uji Statistik}

Dalam uji statistik hipotesa yang digunakan adalah $\mathrm{H}_{0}$ Tidak adanya pengaruh variasi material dan $\mathrm{H}_{1}$ Adanya pengaruh variasi material

Dari uji $\mathrm{F}$ Berdasarkan Konsentrasi $\mathrm{pH}$, didapatkan nilai $\mathrm{F}_{\text {hitung }}=1,048$ dan nilai $\mathrm{F}_{\text {tabel }}$ $=3,354$. Uji $F$ Daya Hantar Listrik didapatkan nilai $F_{\text {hitung }}=0,785$ dan nilai $F_{\text {tabel }}$ $=3,354$. Untuk $\mathrm{pH}$ dan DHL nilai $\mathrm{F}_{\text {hitung }}<$ $\mathrm{F}_{\text {tabel }}$, maka $\mathrm{H} 0$ diterima yang berarti tidak terdapat pengaruh komposisi terhadap hasil pengolahan limbah domestik. Sehingga dapat disimpulkan bahwa reaktor memiliki komposisi berbeda di dalamnya dan tidak mampu untuk meningkatkan nilai $\mathrm{pH}$ dan DHL.

Uji $\mathrm{F}$ untuk TSS diperoleh nilai $\mathrm{F}_{\text {hitung }}=$ 8,857 dan nilai $\mathrm{F}_{\text {tabel }}=3,354$. Uji $\mathrm{F}$ TDS diperoleh nilai $\mathrm{F}_{\text {hitung }}=2,693$ dan nilai $\mathrm{F}_{\text {tabel }}=$ 3,354 . Uji $F$ DO didapatkan nilai $F_{\text {hitung }}=$ 9,850 dan nilai $F_{\text {tabel }}=3,354 . \quad \mathrm{Uji} F$ Kekeruhan diperoleh nilai $\mathrm{F}_{\text {hitung }}=14,070$ dan nilai $F_{\text {tabel }}=3,354$. Baik untuk TSS, TDS, DO dan kekeruhan nilai $F_{\text {hitung }}>F_{\text {tabel }}$, maka H0 ditolak yang berarti terdapat pengaruh komposisi terhadap hasil pengolahan limbah domestik. Sehingga dapat disimpulkan bahwa model reaktor memiliki komposisi berbeda di dalamnya sehingga yang mampu menurunkan kadar baik TSS, TDS, DO maupun kekeruhan.

\section{KESIMPULAN}

Berdasarkan penelitian diperoleh hasil bahwa pada percobaan tahap 1, IPAL MSL dengan lapisan zeolite memiliki hasil paling efisien dalam meningkatkan kualitas air limbah domestik dibandingkan dengan kerikil dan campuran antara zeolite dan kerikil. Lapisan zeolite mempunyai efisiensi untuk pH 3,93-9,13\%, TSS 37,09-59,03\%, 
TDS 9,91-16,07\%, DO 80,05\% - 83,74\%, kekeruhan sebesar $58,79 \%-67,85 \%$, dan daya hantar listrik sebesar 10,39\% - 19,73\%. Pada percobaan tahap 2, IPAL MSL lapisan zeolite ditambah dengan isian tanah dan arang tempurung kelapa mempunyai efisiensi yang paling besar dibandingkan dengan isian tanah dan serbuk gergaji maupun isian tanah dan arang jerami padi. reaktor dengan lapisan zeolite dan dengan isian tanah dan arang tempurung kelapa mempunyai efisiensi untuk pH 4,24-5,77\%, TSS 58,42-71,05\%, TDS $18,05-31,84 \%$, DO 75,06\%-81,88\%, kekeruhan $72,91 \%-76,69 \%$, dan daya hantar listrik sebesar 16,49\% - 31,77\%. Dapat disimpulkan bahwa model IPAL MSL pada penelitian ini sudah dapat digunakan untuk meningkatkan kualitas air pada limbah domestik. Kedepan akan dikembangkan bentuk model IPAL yang lebih ringkas dan sederhana sehingga akan lebih mudah untuk diaplikasikan pada rumah-rumah di Kawasan padat penduduk.

\section{DAFTAR PUSTAKA}

Attanandana, T., Pattnaik, R., Yost, R.S., Porter, G., Masunaga, T. (2007). Improving Multi-Soil-Layer (MSL) System Remediation of Dairy Effluen. Ecological Engineering, 32,1-10.

BSN. (2008). SNI 6774-2008 Tata Cara Perencanaan Unit Paket Instalasi Pengolahan Air. Bandung: BSN.

Haribowo, R., Yoshimura, M., Sekine, M., Imai, T., Yamamoto, K., Higuchi, T. (2017). Behavior Of Toxicity In River Basins Dominated By Residential Areas. Contemporary Engineering Sciences, 10 (7), 305-315.

Irmanto \& Suyata. (2009). Pengolahan Limbah Cair Industri Tahu di Desa Kalisari Kecamatan Cilngok Dengan Metode Multi Soil Layering. Jurnal Universitas Jenderal Soedirman, 4(1), 21-32.

Lahbib Latrach, Naaila Ouazzani, Tsugiyuki Masunaga, Abdessamad Hejjaj, Khadija Bouhoum, Mustapha Mahi, Laila Mandi. (2016). Domestic wastewater disinfection by combined treatment usingmulti-soillayering system and sand filters (MSL-SF): A laboratory pilot study. Ecological Engineering 91 (2016) 294-301.
Luanmanee, S., B., Saitthiti, C., Panichajakhul, \& T. Wakatsuki. (2000). Efficienc of The Multi Soil Layering Systems with Various Organic Material Components on Domestic Wastewater Treatment. May 23 -26, Johannesburg

Mutia, R. (2015). Metode Multi Soil Layering dalam Penyisihan Parameter (COD, TSS dan Amonia) Limbah cair kelapa sawit dengan variasi Hydraulic Loading Rate

Peraturan Daerah Kota Malang. (2017). Peraturan Daerah Kota Malang No.3 Tahun 2017 Tentang Pengendalian Pencemaran Air. Malang: Peraturan Daerah Kota Malang

Peraturan Pemerintah Republik Indonesia. (2001). Peraturan Pemerintah Republik Indonesia No. 82 Tahun 2001 Tentang Pengelolaan Kualitas Air dan Pengendalian Pencemaran Air. Peraturan Pemerintah Republik Indonesia

Rini Wahyu Sayekti, Riyanto Haribowo, Yohana Vivit, Agung Prabowo. (2011). Studi Efektifitas Penurunan Kadar BOD, COD dan $\mathrm{NH}_{3}$ pada Limbah Cair Rumah Sakit dengan Rotating Biological Contactor. Jurnal Teknik Pengairan Vol 2, No 2, 2011.

Sawyer, S. F. (2009). Analysis Of Variance: The Fundanmental Concept. The Journal Of Manual \& Manipulative Therapy, 17 (2), 27-38.

Tahir, Y. T., \& Wakatsuki. (1997). Enhancement and Control of The Functions of Soil Resources for Biogenic Wastewater Treatment by Multi Soil Layering Method, 241 252.

Wakatsuki, T., Esumi, H., Omura, S. (1993). High Performance $N$ and $P$ Removable on Site Domestic Wastewater Treatment System by Multi Soil Layering Method, 27, 3 40

Wakatsuki., T., Luanmanee S., Masunaga, T., Attanandana, T. (2001). Domestik Wastewater and Polluted River Water by Multi Soil Layering Method, Elsivier Press 
Yamashita H., Haribowo, R., Sekine, M., Oda, N., Kanno, A., Shimono, Y. (2012). Toxicity Test Using Medaka (Oryzias Latipes) Early Fry And Concentrated Sample Water As An Index Of Aquatic Habitat Condition. Environmental Science And Pollution Research, 19 (7), 2581-2594.

Yi Zhang, Yan Cheng, Chunping Yang, Wei Luo, Guangming Zeng, Li Luc. (2015). Performance of system consisting of vertical flow trickling filter and horizontal flow multi-soillayering reaktor for treatment of rural wastewater. Bioresource Technology 193 (2015) 424-432.

Zevri, A. (2010). Studi Penyaluran dan Pengolahan Air Limbah di Komplek Pemukiman. Skripsi. Tidak dipublikasikan. Medan: Universitas Sumatera Utara. 